\title{
Fragmentation of Negative Ions from Carbohydrates: Part 2. Fragmentation of High-Mannose $N$-Linked Glycans
}

\author{
David J. Harvey \\ Department of Biochemistry, Glycobiology Institute, University of Oxford, Oxford, United Kingdom
}

$\left[\mathrm{M}+\mathrm{NO}_{3}\right]^{-}$And $\left[\mathrm{M}+\left(\mathrm{NO}_{3}\right)_{2}\right]^{2-}$ ions were produced by electrospray from neutral high-mannose ([Man $]_{5-9}[\mathrm{GlcNAc}]_{2},[\mathrm{Glc}]_{1-3}[\mathrm{Man}]_{4-9}[\mathrm{GlcNAc}]_{2}$ ) $N$-linked glycans and their 2-aminobenzamide derivatives sprayed from methanol:water containing ammonium nitrate. Low energy collision-induced decomposition (CID) spectra of both types of ions were almost identical and dominated by cross-ring and C-type fragments, unlike the corresponding spectra of the positive ions that contained mainly B- and Y-type glycosidic fragments. This behavior could be rationalized by an initial proton abstraction from various hydroxy groups by the initially-formed anionic adduct. These negative ion spectra were more informative than the corresponding positive ion spectra and contained prominent ions that were diagnostic of structural features such as the composition of individual antennas that were not easily obtainable by other means. C-ions defined the sequence of the constituent monosaccharide residues. Detailed fragmentation mechanisms are proposed to account for many of the diagnostic ions. (J Am Soc Mass Spectrom 2005, 16, 631-646) (C) 2005 American Society for Mass Spectrometry

$\mathrm{T}$ The extensive literature on the mass spectrometry of carbohydrates has been mainly concerned with the fragmentation of positive ions, although recent work suggests that fragmentation of negative ions gives complementary information with, in many cases, more specific fragmentation that can reveal finer details of the glycan structure [1-7]. Carbohydrates readily form $[\mathrm{M}-\mathrm{H}]^{-}$ions under electrospray conditions by a mechanism that appears to involve the initial formation of a complex of the type $[\mathrm{M}+\mathrm{X}]^{-}$, where $\mathrm{X}$ is an anion, which then dissociates by loss of $\mathrm{HX}$ to give the $[\mathrm{M}-$ $\mathrm{H}]^{-}$ion. When $\mathrm{X}$ is $\mathrm{OH}^{-}$the complex is unstable and readily disassociates forming both the $[\mathrm{M}-\mathrm{H}]^{-}$ion and several prominent in-source fragments. Other anions, such as $\mathrm{SO}_{4}{ }^{2-}$ [8-10], $\mathrm{Cl}^{-}$[10-14], $\mathrm{Br}^{-}, \mathrm{I}^{-}$, and $\mathrm{NO}_{3}{ }^{-}$, as described in the previous paper [15] on the other hand, form stable complexes that can be transmitted into the collision cell of a mass spectrometer where they fragment to give ions identical to those from the $[\mathrm{M}-\mathrm{H}]^{-}$ions themselves; the initial stage of the fragmentation process again being proton abstraction. The previous paper [15] described the use of anionic adducts for electrospray studies and concluded that the nitrate adduct formed by the addition of ammonium nitrate to the electrospray solution gave the best results in terms of molecular ion stability, detection limit and

Published online March 11, 2005

Address reprint requests to Dr. D. J. Harvey, Department of Biochemistry, Glycobiology Institute, University of Oxford, South Parks Road, Oxford OX1 3QU, United Kingdom. E-mail: dh@glycob.ox.ac.uk production of diagnostic fragment ions. This method has now been applied to the structural determination of several types of carbohydrate derived from glycoproteins and glycolipids.

Glycoproteins can contain carbohydrates attached to several sites; in mammalian systems linkage is to asparagine ( $N$-linked glycans) residues in an Asn-XxxSer(Thr) or occasionally an Asn-Xxx-Cys motif where $\mathrm{Xxx}$ is any amino acid except proline, or to either serine or threonine (O-linked glycans). $\mathrm{N}$-Linked glycans are biosynthesised by the attachment of the tetradecaose, $(\mathrm{Glc})_{3}(\mathrm{Man})_{9}(\mathrm{GlcNAc})_{2}$ (Compound 9, Figure 1) to the amide group of asparagine, followed initially by enzymatic removal of the three glucose residues to leave $(\mathrm{Man})_{9}(\mathrm{GlcNAc})_{2}$, (7) a member of the high-mannose series of $N$-linked glycans (Figure 2). Mannose (Man) residues are then removed from the non-reducing terminus to give (Man $)_{5}(\mathrm{GlcNAc})_{2}(2)$, the starting glycan for subsequent chain elongation to give hybrid and complex glycans. This paper describes the fragmentation of these and related high-mannose $N$-linked glycans and proposes mechanisms for the formation of the diagnostic ions.

\section{Materials and Methods}

\section{Materials}

High-mannose glycans were released with hydrazine $[16,17]$ from chicken ovalbumin (Compound 1) [18, 

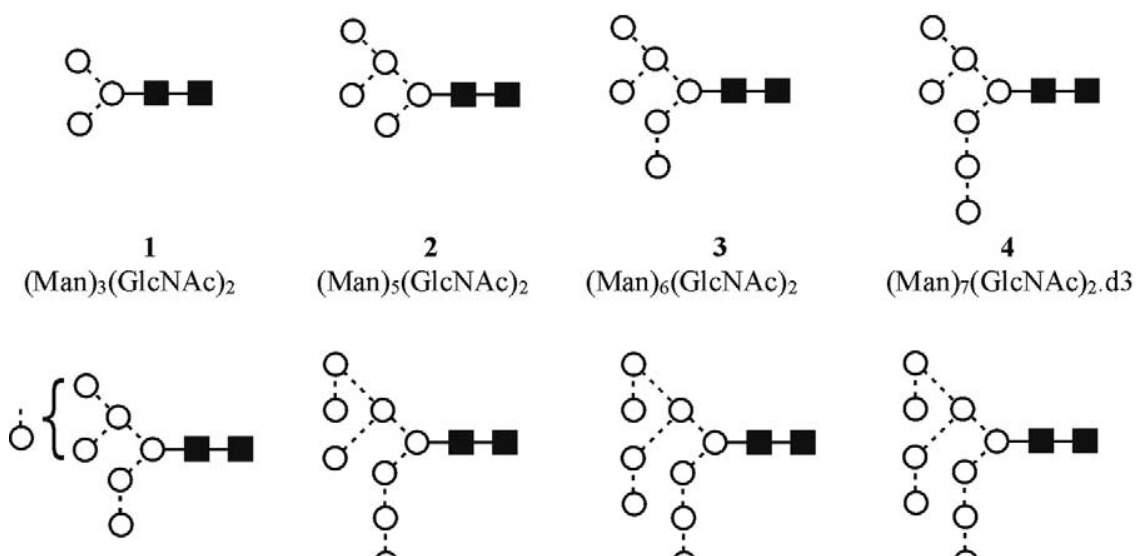

(Man) $)_{5}(\mathrm{GlcNAc})_{2}$

$(\mathrm{Man})_{6}(\mathrm{GlcNAc})_{2}$

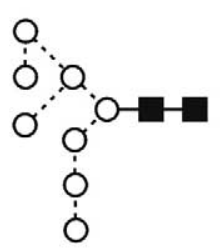

5

$(\mathrm{Man})_{7}(\mathrm{GlcNAc})_{2}$

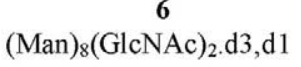
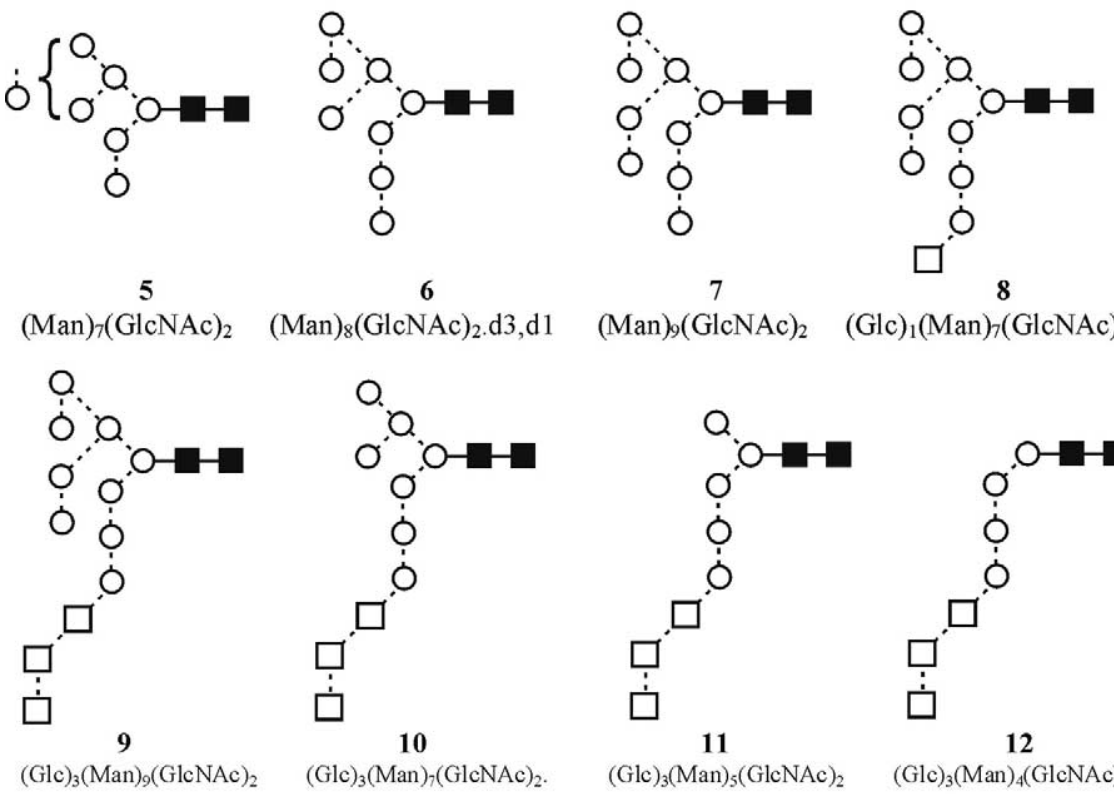

$(\mathrm{Man})_{9}(\mathrm{GlcNAc})_{2}$

$(\mathrm{Glc})_{1}(\mathrm{Man})_{7}(\mathrm{GlcNAc})_{2}$

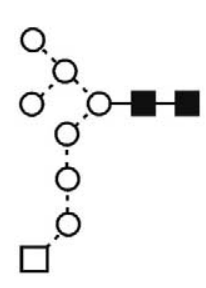

13

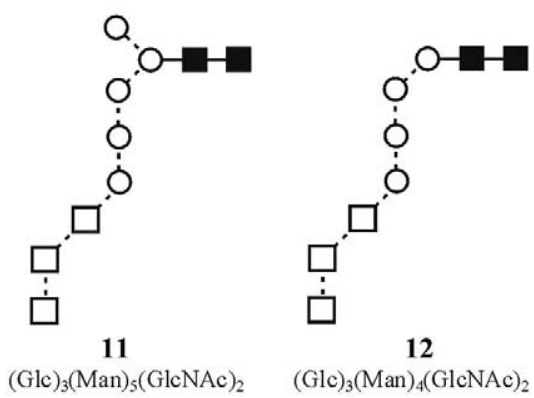

$(\mathrm{Glc})_{3}(\mathrm{Man})_{5}(\mathrm{GlcNAc})_{2} \quad(\mathrm{Glc})_{3}(\mathrm{Man})_{4}(\mathrm{GlcNAc})_{2}$

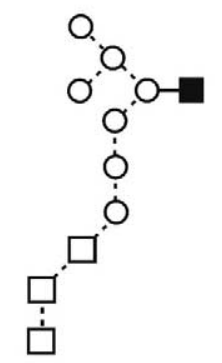

14

$(\mathrm{Glc})_{1}(\mathrm{Man})_{7}(\mathrm{GlcNAc})_{2} \quad(\mathrm{Glc})_{3}(\mathrm{Man})_{7}(\mathrm{GlcNAc})_{1}$

Figure 1. Structures of the glycans whose fragmentation is discussed in this paper. Key to symbols for this and subsequent figures: open circle $=$ mannose, filled square $=$ GlcNAc, open square $=$ glucose. Linkage position is shown by the angle of the lines connecting the monosaccharide symbols (vertical line $=1 \rightarrow 2$, forward slash $=1 \rightarrow 3$, horizontal line $=1 \rightarrow 4$, backward slash $=1 \rightarrow 6$ ); full line $=\beta$-bond, broken line $=\alpha$-bond.

19] ribonuclease $B$ (Compounds 2, 3) [20] and porcine thyroglobulin $(\mathbf{2}, \mathbf{3}, \mathbf{5}-\mathbf{7})[21,22]$ obtained from Sigma Chemical Co. Ltd. (Poole, Dorset, UK); immunoglobulin $\mathrm{Y}(\mathbf{8})$ and Chinese hamster ovary $(\mathrm{CHO})$ cells (9-12), (Man $)_{7}(\mathrm{GlcNAc})_{2} \cdot \mathrm{d} 3$ (4), and $(\mathrm{Man})_{8}(\mathrm{GlcNAc})_{2}$ $\cdot \mathrm{d} 1, \mathrm{~d} 3$ (6) were purchased from Oxford Glycosciences Ltd. (Abingdon, UK). $(\mathrm{Glc})_{3}(\mathrm{Man})_{7}(\mathrm{GlcNAc})_{1}(\mathbf{1 3})$ was obtained as a by-product from the isolation of $(\mathrm{Glc})_{3}(\mathrm{Man})_{7}(\mathrm{GlcNAc})_{2}$. Ammonium nitrate was from Aldrich Chemical Co. Ltd. (Poole, UK). Methanol was obtained from BDH Ltd. (Poole, UK). Water was distilled before use.
Preparation of 2-Aminobenzamide (2-AB) Derivatives

2-AB Derivatives were prepared by reductive amination by a modification of the method described by Bigge et al. [23]. ${ }^{\circ}$ Glycans ${ }^{\circ}$ were ${ }^{\circ}$ dissolved ${ }^{\circ}{ }^{\circ}$ dimethylsulfoxide $(20 \mu \mathrm{L})$ and acetic acid $(2 \mu \mathrm{L})$ and an excess of $2-\mathrm{AB}$ was added. The mixture was heated for $5 \mathrm{~min}$ at $80^{\circ} \mathrm{C}$ to form the Schiff base before addition of the reducing agent in order to avoid production of the reduced, underivatized glycan that can occur under the published conditions. The mixture was cooled and an 


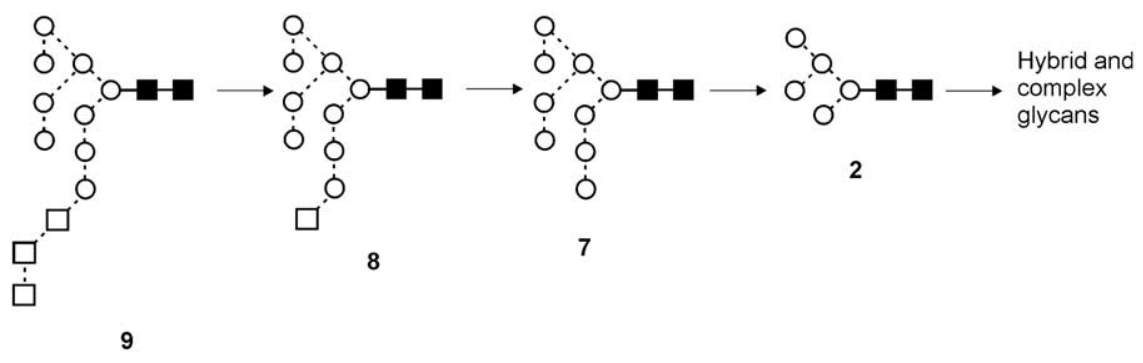

Figure 2. Biosynthetic route involving high-mannose glycans.

excess of sodium cyanoborohydride, was added. Heating was continued for a further $2 \mathrm{~h}$. The solution was then applied $1 \mathrm{~cm}$ from the end of a $10 \mathrm{~cm}$ strip of Whatman 3MM Chr paper, allowed to dry and the reagents were removed by ascending chromatography in acetonitrile leaving the derivatized glycans at the origin. These glycans were extracted with water $(200 \mu \mathrm{L}$ plus a further $100 \mu \mathrm{L}$ ) and desalted with a small column of AG50 resin (100-200 mesh) which was washed with a further $50 \mu \mathrm{L}$ of water.

\section{Electrospray Mass Spectrometry}

Electrospray mass spectrometry was performed with a Waters-Micromass quadrupole-time-of-flight (Q-TOF) Ultima Global instrument (Waters/Micromass Ltd., Manchester, UK) as described in the accompanying paper ${ }^{\circ}[15]$.

\section{Investigations of the Effect of the RF-1} and Collision Cell Voltages

Glycans in solutions containing ammonium nitrate were infused at $5 \mathrm{~mL} / \mathrm{min}$ at a concentration of about $50 \mathrm{pmol} / \mu \mathrm{L}$ and spectra were recorded for $20 \mathrm{~s}$ with an acquisition time of $2 \mathrm{~s}$ (10 scans). For measurements of the effect of the RF-1 potential, this voltage was raised in $10 \mathrm{~V}$ steps from 0 to $250 \mathrm{~V}$ and spectra were recorded at each voltage. For measurements of the effect of collision cell potential, this was raised in $2 \mathrm{~V}$ steps and later at larger voltage increments from the voltage at which the fragments started to appear until most ions had fragmented. The total ion current was plotted against voltage. For these latter measurements, the RF-1 voltage was set at 250 and $80 \mathrm{~V}$ for the singly- and doubly-charged, respectively.

\section{Results and Discussion}

\section{Ion Nomenclature}

Although the ion nomenclature proposed by Domon and ${ }^{\circ} \mathrm{Costello}^{\circ}[24]^{\circ}$ to $^{\circ}$ name ${ }^{\circ}$ the ${ }^{\circ}$ fragment ${ }^{\circ}$ ions ${ }^{\circ}$ is ${ }^{\circ}$ used $^{\circ}$ in this paper, confusion can arise when ions from glycans with antennas of different length are discussed because of changes to the subscript numbers defining the positions in the chains that are cleaved. For example, with high-mannose glycans, the $\mathrm{B}$ ion formed by cleavage of the reducing terminal GlcNAc residue is $\mathrm{a}_{4}$ ion from $(\mathrm{Man})_{5}(\mathrm{GlcNAc})_{2} \quad$ (Compound $^{\circ}$ 2, Figure $\left.^{\circ} 1\right)^{\circ}$ and $(\mathrm{Man})_{6}(\mathrm{GlcNAc})_{2}(3)$ but a $\mathrm{B}_{5}$ ion from (Man $)_{7-9}(\mathrm{GlcNAc})_{2}$ (4-7) because of the extended antennas. Thus, for discussion purposes, the subscript for this ion will be $\mathrm{R}$ (for reducing terminus), i.e., the $B_{R}$ ion refers to the $B$ ion formed by loss of the reducing terminal GlcNAc residue. By extension, the B ion formed by cleavage of the next (penultimate) GlcNAc residue will be referred to as the $B_{R-1}$ ion. Similarly, $Y$ fragments arising from the non-reducing terminus will be referred to as $\mathrm{Y}_{\mathrm{NR}}$ and $\mathrm{Y}_{\mathrm{NR}-1}$ etc. ions. The numbering system for fragments retains that for the molecular ion.

\section{Fragmentation of Singly-Charged Ions}

As observed earlier for $N$-linked glycans and other carbohydrates ${ }^{\circ}[1-7]$, the $^{\circ}$ low $^{\circ}$ energy $^{\circ}$ negative ${ }^{\circ}$ ion ${ }^{\circ}$ spectra contained mainly ions produced by C-type and cross-ring cleavages unlike the spectra of positive ions such as $[\mathrm{M}+\mathrm{Na}]^{+}$that gave mainly $\mathrm{B}-$ and $\mathrm{Y}$-ions. This observation can be rationalized by proton abstraction from various hydroxyl groups to leave an electrondense center that readily feeds electrons into the sugar rings, causing them to cleave. It was also noted that cleavages were much more specific than in the positive ion spectra such that "internal fragments" (fragments produced by cleavages at multiple sites) were less common with the result that many fragment ions were only formed by one pathway and were diagnostic of specific structural features of the glycans.

Spectra reported in this paper were recorded at a collision cell voltage that gave an even distribution of fragments across the mass range. However, as the presence of fragments was dependent on the collision cell voltage, not all possible fragments are represented in the spectra shown in the figures as they could be present in voltage ranges outside of that shown. Several examples are illustrated below.

\section{Ions Produced by Fragmentation} of the Chitobiose Core

Ions produced by cleavages at the reducing terminus were common to the spectra of all the $N$-linked glycans. The most abundant were the ${ }^{2,4} \mathrm{~A}_{\mathrm{R}}$ and ${ }^{2,4} \mathrm{~A}_{\mathrm{R}-1}$ ions at 


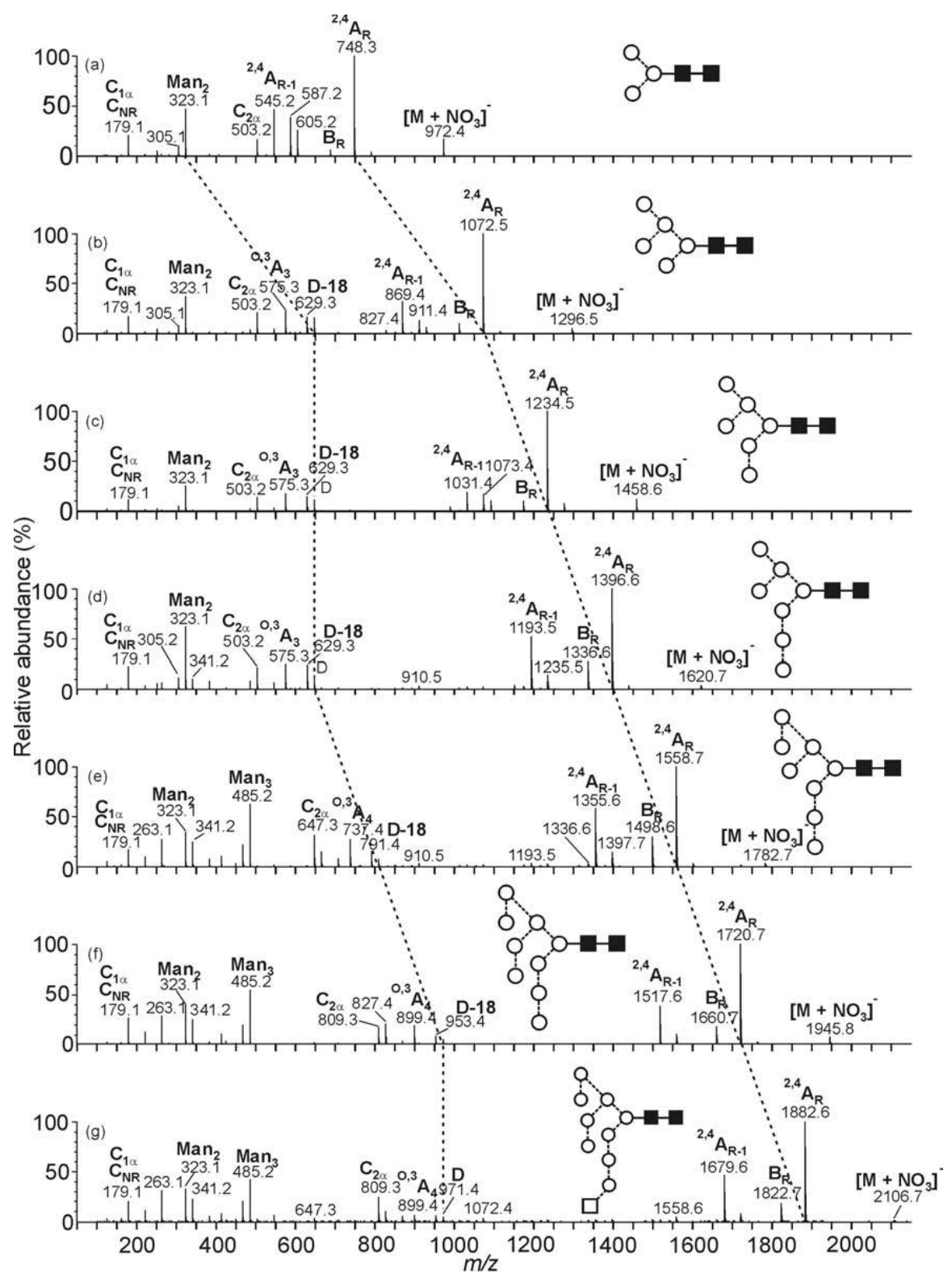

Figure 3. CID spectrum of the $\left[\mathrm{M}+\mathrm{NO}_{3}\right]^{-}$ion from (a) $(\mathrm{Man})_{3}(\mathrm{GlcNAc})_{2}(\mathbf{1}),(\mathbf{b})(\mathrm{Man})_{5}(\mathrm{GlcNAc})_{2}$ (2), (c) $\quad(\mathrm{Man})_{6}(\mathrm{GlcNAc})_{2} \quad$ (3), (d) $\quad(\mathrm{Man})_{7}(\mathrm{GlcNAc})_{2}, \mathrm{~d} 3 \quad$ (4), (e) (Man) $)_{8}(\mathrm{GlcNAc})_{2}, \mathrm{~d} 1, \mathrm{~d} 3 \quad$ (6), (f) $(\mathrm{Man})_{9}(\mathrm{GlcNAc})_{2}(7),(\mathrm{g})(\mathrm{Glc})_{1}(\mathrm{Man})_{9}\left(\mathrm{GlcNAc}_{2}(\mathbf{8})\right.$. The broken lines show movement of the D-ions and ${ }^{2,4} \mathrm{~A}_{\mathrm{R}}$ ions with increasing mannose substitution.

$[\mathrm{M}-\mathrm{HR}-161]^{-}$and $[\mathrm{M}-\mathrm{HR}-364]^{-}$, respectively, (where $\mathrm{R}$ is the attached anion). For example, in the spectra of the underivatized high-mannose glycan, $(\mathrm{Man})_{5}(\mathrm{GlcNAc})_{2}\left(2\right.$ Figures $\left.^{\circ} 3 \mathrm{~b},{ }^{\circ} 4 \mathrm{a}\right){ }^{\circ}{ }^{\circ}$ these ${ }^{\circ}$ two ${ }^{\circ}$ ions appeared at $m / z 1072.4\left({ }^{2,4} \mathrm{~A}_{\mathrm{R}}\right)$ and $869.4\left({ }^{2,4} \mathrm{~A}_{\mathrm{R}-1}\right)$ respectively. Formation of the ${ }^{2,4} \mathrm{~A}_{\mathrm{R}}$ ion can be rationalized by initial abstraction of a hydroxylic proton from the 3-position of the reducing-terminal GlcNAc residue as shown in Scheme 1 followed by electron shifts that result in ring cleavage. Mechanisms for the cleavage of the reducing terminal sugar ring to produce both ${ }^{\mathrm{O}, 2} \mathrm{~A}$ and ${ }^{2,4} \mathrm{~A}$ ions have previously assumed initial abstraction $^{\circ}$ of $^{\circ}$ the ${ }^{\circ}$ allylic ${ }^{\circ}$ hydroxylic ${ }^{\circ}$ proton $^{\circ}$ from ${ }^{\circ} \mathrm{C}-1^{\circ}[25]$ followed ${ }^{\circ}$ by $^{\circ}{ }^{\circ}{ }^{\circ}$ retro-aldol ${ }^{\circ}$ rearrangement ${ }^{\circ}\left[26,{ }^{\circ} 27\right],{ }^{\circ}$ even though the proton from the 3-hydroxyl group has been shown ${ }^{\circ}$ to ${ }^{\circ}$ ave ${ }^{\circ}$ considerable ${ }^{\circ}$ acidity ${ }^{\circ}[28] .{ }^{\circ}$ However, ${ }^{\circ}$ the retro-aldol mechanism can be discounted on several grounds. In order for the charge to remain with the non-reducing fragment, unnecessary hydrogen migrations $^{\circ}$ have $^{\circ}$ to $^{\circ}$ be $^{\circ}$ invoked $^{\circ}[26]^{\circ}{ }^{\circ}$ otherwise, ${ }^{\circ}$ the ${ }^{\circ}$ charge would remain associated with the small fractions (C-1, C-2, C-5, C-6) of the reducing terminal GlcNAc residue. Secondly, the ${ }^{2,4} A_{R}$ ion was not seen in the spectra of the $2-\mathrm{AB}^{\circ}$ derivatives ${ }^{\circ}$ (Figure $\left.{ }^{\circ} 4 \mathrm{~b}\right)^{\circ}$ that ${ }^{\circ}{ }^{\circ}$ hve $^{\circ}$ an $^{\circ}$ open ${ }^{\circ}$ reducing-terminal ring. This structure is equivalent to the intermediate involved in the retro-aldol mechanism.

The ${ }^{2,4} \mathrm{~A}_{\mathrm{R}-1}$ ion, on the other hand, was relatively abundant in the spectra of the glycans derivatized at the 


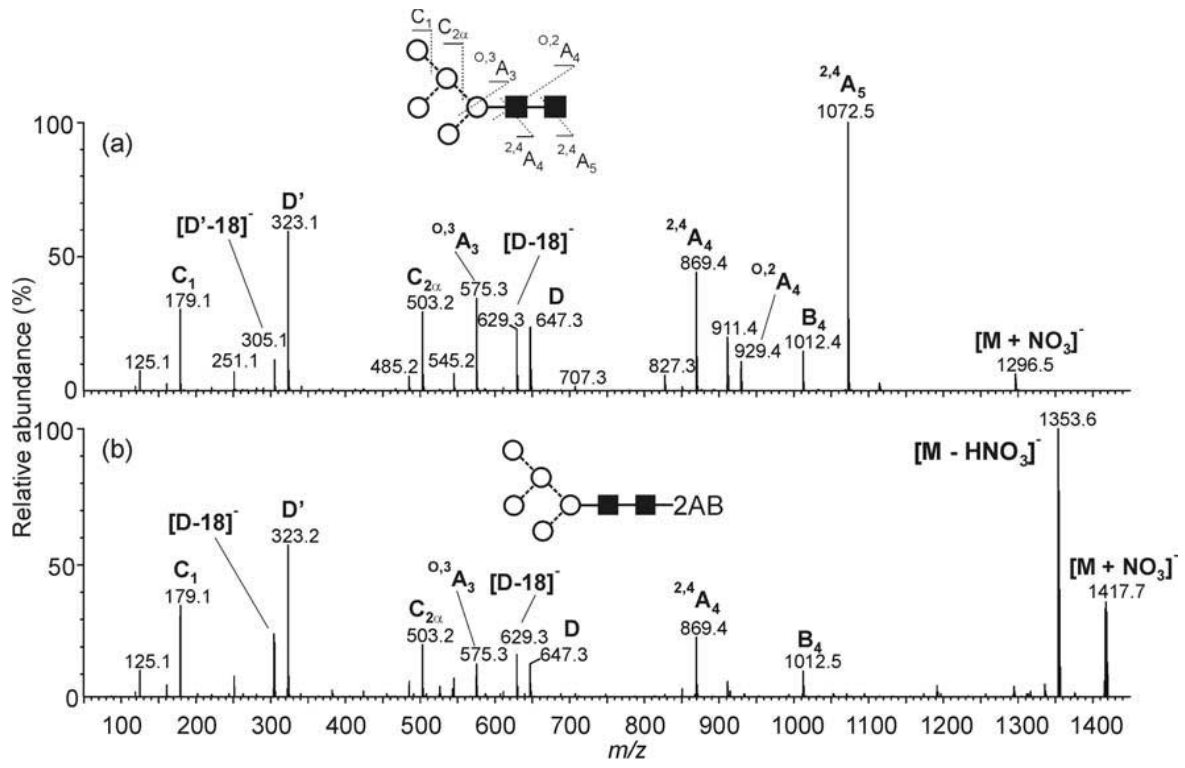

Figure 4. CID spectrum of the $\left[\mathrm{M}+\mathrm{NO}_{3}\right]^{-}$ion from (a) (Man) $)_{5}(\mathrm{GlcNAc})_{2}(2)$ and (b) the 2-AB derivative of (Man $)_{5}(\mathrm{GlcNAc})_{2}$ (2).

reducing ${ }^{\circ}$ terminus ${ }^{\circ}\left(\text { Figure }^{\circ} 4 \mathrm{~b}\right)^{\circ}$ indicating $^{\circ} \mathrm{a}^{\circ}$ fragmentation route involving initial abstraction of a proton other than that from the 3-position of the reducing-terminal GlcNAc residue. This conclusion was supported by the $M S^{3}$ spectrum of the ${ }^{2,4} A_{R}$ ion from the underivatized glycans $^{\circ}$ generated $^{\circ}$ within $^{\circ}$ the ${ }^{\circ}$ ion $^{\circ}$ source $^{\circ}\left(\right.$ Figure $\left.^{\circ} 5 a\right)$, which showed no ion corresponding to ${ }^{2,4} \mathrm{~A}_{\mathrm{R}-1}$ and confirmed that the ${ }^{2,4} \mathrm{~A}_{\mathrm{R}-1}$ ion arose exclusively from the molecular ion. A possible mechanism involving initial abstraction of a proton from 3-hydroxyl group of the penultimate (R-1) GlcNAc ring is suggested in Scheme 2 to account for the presence of the ${ }^{2,4} \mathrm{~A}_{\mathrm{R}-1}$ ion (Ion $b$ ). Further support for the structure of this ion came from its $^{\circ}$ MS $^{3^{\circ}}$ spectrum $^{\circ}$ (Figure ${ }^{\circ} 5$ b). ${ }^{\circ}$ Although ${ }^{\circ}$ similar $^{\circ}$ in structure to ion $a$, the $\mathrm{MS}^{3}$ spectrum of ion $b$ was very different to that of Ion $a$ in that it showed mainly successive losses of mannose residues. The reason appears to be that further charge migration in the ${ }^{2,4} \mathrm{~A}_{\mathrm{R}}$ ion (ion $a$ ) can lead to the $\mathrm{C}_{\mathrm{R}-2^{\circ}}\left(\mathrm{C}_{3}, 9 m / z\right.$ 827.3, Figures $\left.{ }^{\circ} \mathrm{b},{ }^{\circ} 4 \mathrm{a}\right)$ fragment (Ion $c$ ) as shown in Scheme 3, whereas a similar charge migration cannot produce this fragment from the ${ }^{2,4} \mathrm{~A}_{\mathrm{R}-1}$ ion. As described below, further fragmentation of Ion $c$ appears to produce many of the ions of lower mass in these spectra and is consistent with the difference between the two $\mathrm{MS}^{3}$ spectra shown in Figure ${ }^{\circ} 5^{\circ}$ and ${ }^{\circ}$ the $e^{\circ}$ similarity ${ }^{\circ}$ between ${ }^{\circ}$ the ${ }^{\circ} \mathrm{MS}^{3^{\circ}}$ spectrum shown ${ }^{\circ}$ in ${ }^{\circ}$ Figure ${ }^{\circ} 5 \mathrm{a}^{\circ}$ and ${ }^{\circ}$ that ${ }^{\circ}$ of ${ }^{\circ}$ the $e^{\circ}$ parent ${ }^{\circ}$ ion.

Proton abstraction from the 6-position of the two GlcNAc residues would also give rise to C-type cleavage ions, such as Ion c, as shown in Scheme 4 for the penultimate (R-1) GlcNAc residue and mechanisms of this type probably explain the predominance of Ccleavages over B- and Y-type cleavages seen in these negative ion ${ }^{\circ}$ spectra ${ }^{\circ}$ and $^{\circ}$ as ${ }^{\circ}$ reported by $^{\circ}$ others ${ }^{\circ}[1-5] .{ }^{\circ}$ As discussed below, the $\mathrm{C}$-ions formed from the reducing end of the molecules, such as Ion $c$, were relatively unstable and were only seen at low collision energies (Figures ${ }^{\circ} 6^{\circ}$ and $\left.^{\circ} 7\right)^{\circ}$ because $^{\circ}$ of $^{\circ}$ the ${ }^{\circ}$ possibility ${ }^{\circ} f^{\circ}$ further
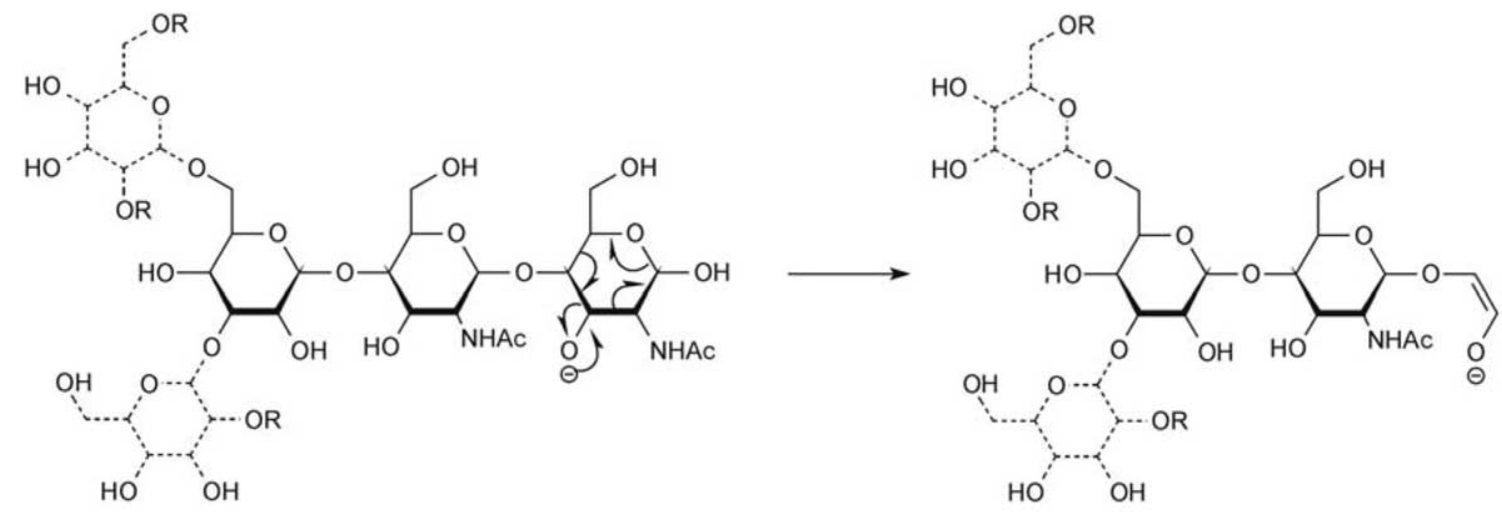

Ion $a$

Scheme 1. Proposed mechanism for the formation of the $[M-161]^{-}$ion $\left({ }^{2,4} A_{R}\right.$, Ion $\left.a\right)$. 


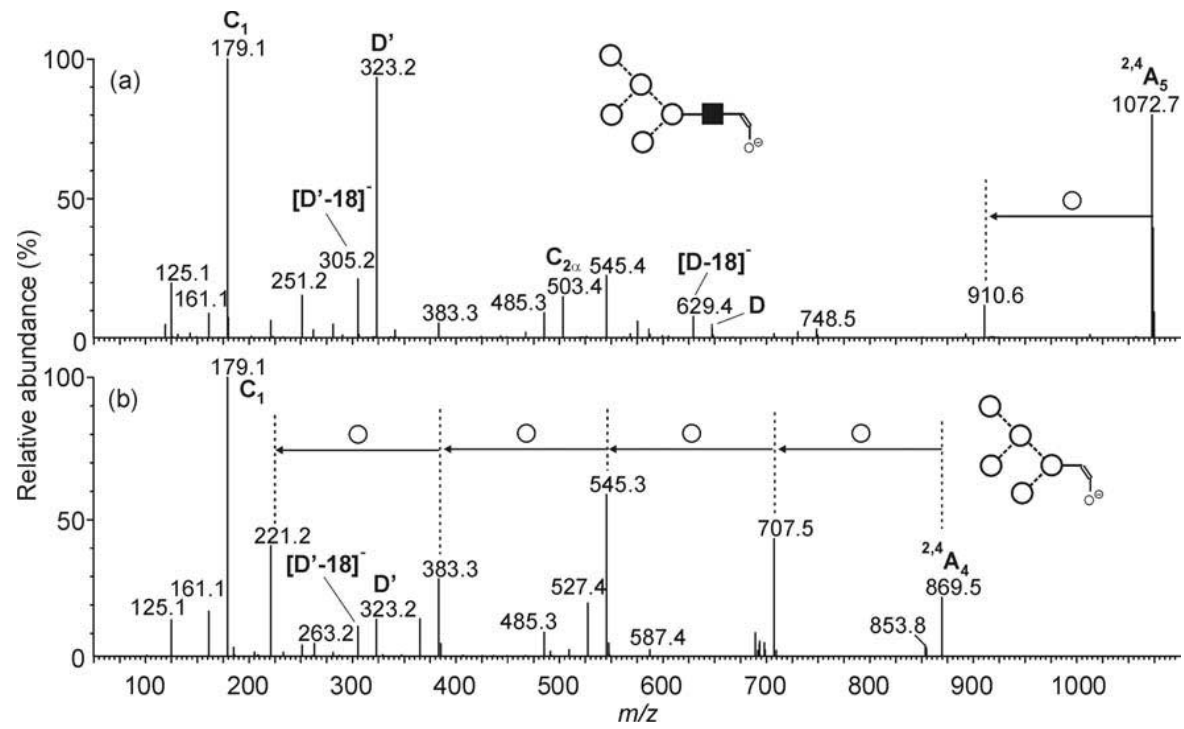

Figure 5. $\mathrm{MS}^{3}$ spectrum of $(\mathbf{a})$ the $[\mathrm{M}-161]^{-}$ion $\left({ }^{2,4} \mathrm{~A}_{\mathrm{R}}\right.$, Ion $\left.a\right)$ and $(\mathbf{b})$ the $[\mathrm{M}-161-203]^{-}$ion $\left({ }^{2,4} \mathrm{~A}_{\mathrm{R}-1}\right.$, Ion $\left.b\right)$ from $(\mathrm{Man})_{5}(\mathrm{GlcNAc})_{2}(2)$.

fragmentation. Those from the non-reducing terminus were more abundant as there was less opportunity for further ${ }^{\circ}$ cleavages. ${ }^{\circ}$ The ${ }^{\circ}$ spectra ${ }^{\circ}$ shown ${ }^{\circ}{ }^{\circ}{ }^{\circ}$ Figure $^{\circ} 6^{\circ}$ are ${ }^{\circ}$ of the $[\mathrm{M}-\mathrm{H}]^{-}$rather than the $[\mathrm{M}-\mathrm{HR}]^{-}$ions but both types of ion fragmented in an identical manner as shown by a comparison of the spectrum shown in Figure ${ }^{\circ} 6 \mathrm{~b}^{\circ}$ with $^{\circ}$ that ${ }^{\circ}$ of $^{\circ}$ the ${ }^{\circ}$ nitrate ${ }^{\circ}$ adduct ${ }^{\circ}$ (Figure ${ }^{\circ} 3 \mathrm{~b}$ ).

Also seen only at low collision energy was an ${ }^{0,2} A_{R}$ cross-ring fragment $(\mathrm{m} / \mathrm{z} 1132.3$ from Compound 2 and 1294.3 from 3), whose intensity maximized at a collision cell $^{\circ}$ voltage $^{\circ}$ of $^{\circ} 20^{\circ}$ volts $^{\circ}$ (Figure ${ }^{\circ}$ ). ${ }^{\circ}$ This ${ }^{\circ}$ fragment ${ }^{\circ}$ and ${ }^{\circ}$ its $-\mathrm{H}_{2} \mathrm{O}$ counterpart had decomposed at the collision cell

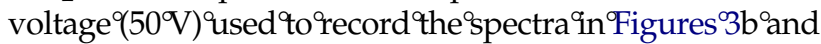
4a. ${ }^{\circ}$ Similarly, ${ }^{\circ}$ the ${ }^{\circ}$ intensity ${ }^{\circ}$ of $^{\circ}$ the ${ }^{\circ \mathrm{O}, 2} \mathrm{~A}_{\mathrm{R}-1}$ ion $(\mathrm{m} / \mathrm{z} 929.3$ from Compound 2 and $\mathrm{m} / \mathrm{z} 1091.3$ from 3 ) maximized at $30 \mathrm{~V}$ and was insignificant at $50 \mathrm{~V}$. These ions probably arise from related mechanisms to those proposed for formation of the ${ }^{2,4} A_{R}$ and ${ }^{2,4} A_{R-1}$ ions (Schemes 1 and 2) but with the charge movement stopping with the charge on the ring oxygen atom (Ion $d$ ) as shown in Scheme 5. At higher energies, further bond cleavage occurs to produce the ${ }^{2,4} \mathrm{~A}_{\mathrm{R}}$ and ${ }^{2,4} \mathrm{~A}_{\mathrm{R}-1}$ ions as shown in Schemes 1 and 2. Increasing the energy further produces the C-type fragment, Ion $c$, from the ${ }^{2,4} \mathrm{~A}_{\mathrm{R}}$ ion which then fragments to give many of the other diagnostic ions.

The ${ }^{2,4} \mathrm{~A}_{\mathrm{R}-1}$ ion, which is unable to produce Ion $c$, fragmented by loss of mannose residues in the spectra of $^{\circ}$ the ${ }^{\circ}$ high-mannose ${ }^{\circ}$ glycans ${ }^{\circ}$ (Figures ${ }^{\circ} 3 b^{\circ}$ and $^{\circ} 4 a$ ), ${ }^{\circ}$ possibly by a charge-remote process or, more probably, by a charge-induced mechanism. Such a mechanism is needed in order to account for some of the specific secondary eliminations that were seen in the spectra of the ${ }^{\circ}$ complex $^{\circ}$ glycans ${ }^{\circ}$ (see [29]). ${ }^{\text {S Such }}{ }^{\circ}{ }^{\circ}$ mechanism ${ }^{\circ}$ could involve a hydrogen migration to the charge site of ions of type $b$ resulting in the charge migrating to the site

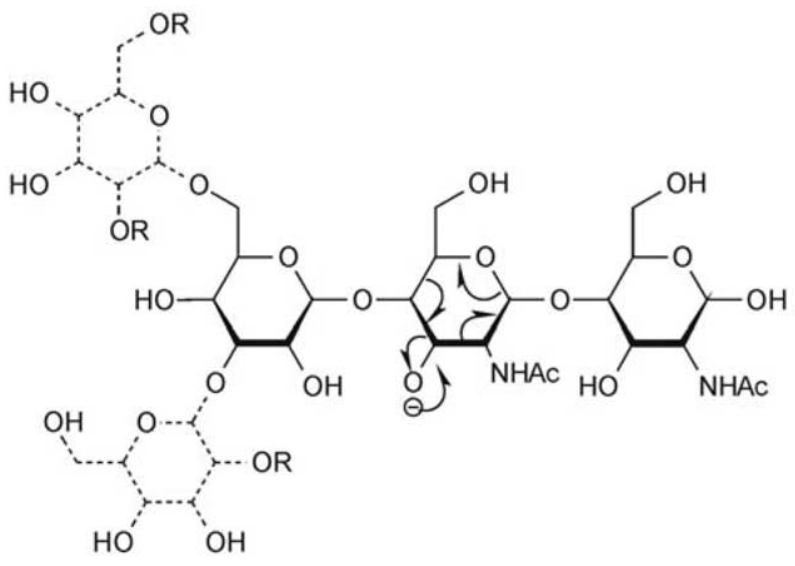<smiles>[R2]C[C@H]1O[C@H](OCC2OC(O/C=C\[O-])C(O)C(O[C@@H]3O[C@H](CO)[C@@H](O)[C@H](O)[C@H]3O[R])C2O)[C@H]([2H])[C@@H](O)[C@H]1O</smiles>

Ion $b$

Scheme 2. Proposed mechanism for the formation of the $[M-161-203]^{-}$ion $\left({ }^{2,4} A_{R-1}\right.$, Ion $\left.b\right)$. 

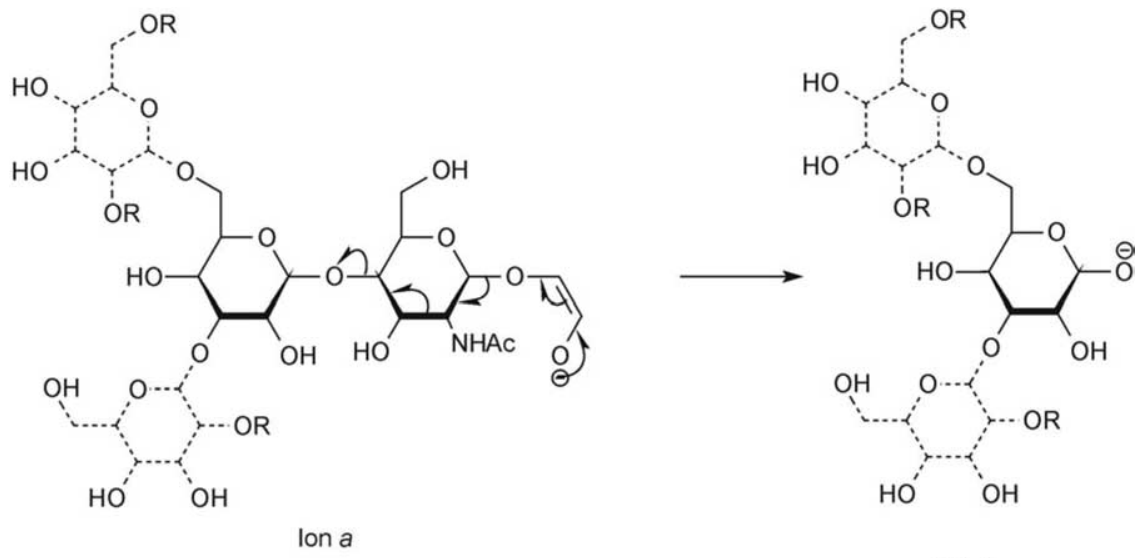

Scheme 3. Proposed mechanism for the formation of the $C_{3}$ ion (Ion $c$ ).

from which the original hydrogen atom had been abstracted, leaving a second negatively-charged oxygen atom that can trigger further cleavages. In effect, the primary charge site is proposed to act as a secondary proton scavenger in a manner similar to that occurring in the fragmentation of positive ions from derivatized long-chain ${ }^{\circ}$ fatty $^{\circ}$ acids $^{\circ}$ and $^{\circ}$ alcohols $^{\circ}\left[30^{\circ}-34\right]$.

Prominent ions corresponding to losses of 221 mass units $^{\circ}$ from ${ }^{\circ}$ the ${ }^{\circ}\left[\mathrm{M}^{\circ}-{ }^{\circ} \mathrm{H}\right]^{\circ}$ ion $^{\circ}\left(\mathrm{m} / \mathrm{z} 1012.4^{\circ}\right.$ in $^{\circ}$ Figure $^{\circ} 3 \mathrm{~b}$ appeared to be B-type fragments formed by loss of the reducing terminal GlcNAc residue with a hydrogen migration to the eliminated fragment. A possible mechanism is suggested in Scheme 6 . Loss of the hydrogen atom from the 4-position of the R-1 GlcNAc residue is speculative but supported by the stability of the product ion (similar to Ions $a$ and $b$ ) and the axial nature of the hydrogen atom which would allow it to approach the glycosidic oxygen atom linking the two GlcNAc residues after ionization and cleavage of the $\mathrm{C}-2-\mathrm{C}-3$ bond shown in Scheme 6 . No other hydrogen atom can conveniently approach to within bonding distance as easily. It has frequently been observed under electronimpact conditions that neutral losses from cyclohexane rings ${ }^{\circ}$ involve ${ }^{\circ} 1,4$-eliminations ${ }^{\circ}$ of $^{\circ}$ this $^{\circ}$ type ${ }^{\circ}[35],{ }^{\circ}$ sometimes after conversion of chair to boat configurations [36].$^{\circ} \mathrm{A}^{\circ}$ similar $^{\circ}$ hydrogen ${ }^{\circ}$ migration $^{\circ}$ from $^{\circ}$ carbon $^{\circ}$ to $^{\circ} \mathrm{a}$ linking oxygen atom has recently been proposed to account for the formation of Z-type ions in the dissociation $^{\circ}$ of $^{\circ}$ heparin ${ }^{\circ} \operatorname{dimers}^{\circ}[27]$.

\section{Ions Specific to the 6-Antenna}

The spectra of the glycans $\mathbf{2 - 1 0}$ contained several ions that were diagnostic of the individual antenna composition. The ion at $\mathrm{m} / \mathrm{z} 647.3$ in the spectrum of $(\mathrm{Man})_{5}(\mathrm{GlcNAc})_{2^{\circ}} \quad\left(\mathbf{2}, \text { Figures }^{\circ} 3 \mathrm{~b}^{\circ} \text { and }^{\circ} 4 \mathrm{a}\right)^{\circ}$ and $(\mathrm{Man})_{6}(\mathrm{GlcNAc})_{2^{\circ}}\left(3 \text {, Figure }^{\circ} 3 \mathrm{c}\right)^{\circ}$ had $^{\circ}$ the $^{\circ}$ composition $^{\circ}$ of $\left[(\mathrm{Man})_{4}-\mathrm{H}_{2} \mathrm{O}-\mathrm{H}\right]^{-}$and was equivalent to the ion of similar composition reported earlier from high-resolution ${ }^{\circ} \mathrm{CID}{ }^{\circ}$ spectra ${ }^{\circ}$ ff $^{\circ}\left[\mathrm{M}^{\circ}+{ }^{\circ} \mathrm{Na}\right]^{+}{ }^{\circ}$ ions $9[37]^{\circ}$ and ${ }^{\circ}$ termed ${ }^{\circ}$ ion D. It contained the intact 6-antenna and the branching mannose and defined the composition of this antenna. However, unlike its counterpart in the positive ion spectra that appeared to be formed by several routes [38], ${ }^{\circ}$ the ${ }^{\circ}$ peak $^{\circ}$ at $^{\circ}$ this ${ }^{\circ} \mathrm{m} / z$ value ${ }^{\circ}$ in $^{\circ}$ the ${ }^{\circ}$ negative ${ }^{\circ}$ ion spectra appeared not to be produced by any additional internal cleavage pathway and was, thus, diagnostic of the composition of the 6-antenna. Similar ions have been reported from large, sialylated $N$-linked glycans $[7]^{\circ}$ and $^{\circ}$ sugars ${ }^{\circ}$ from ${ }^{\circ}$ human ${ }^{\circ}$ milk $^{\circ}[5]^{\text {but }}{ }^{\circ}$ detailed ${ }^{\circ}$ mech-
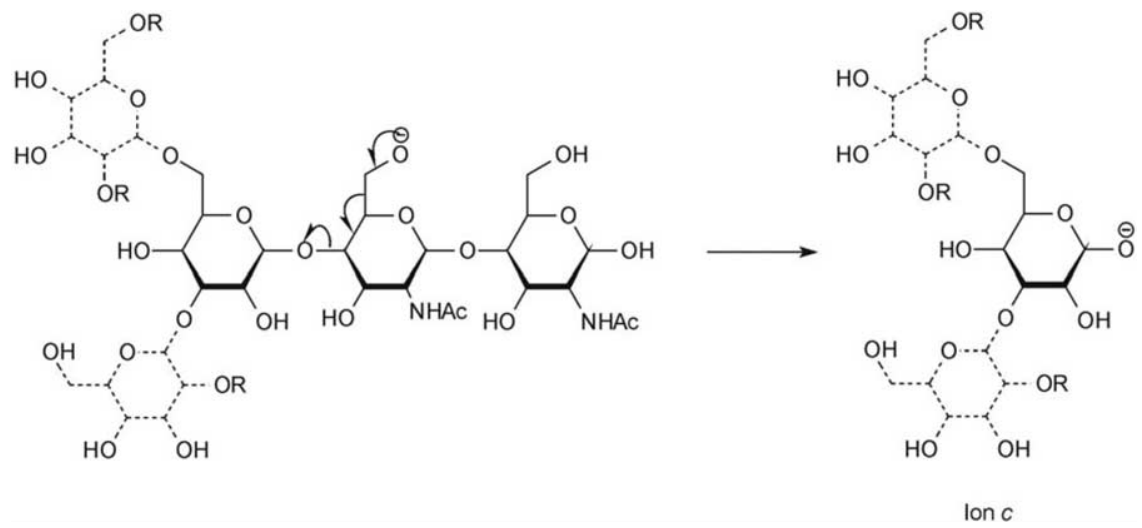

Scheme 4. Proposed alternative mechanism for formation of the $C_{3}$ ion (Ion $c$ ). 


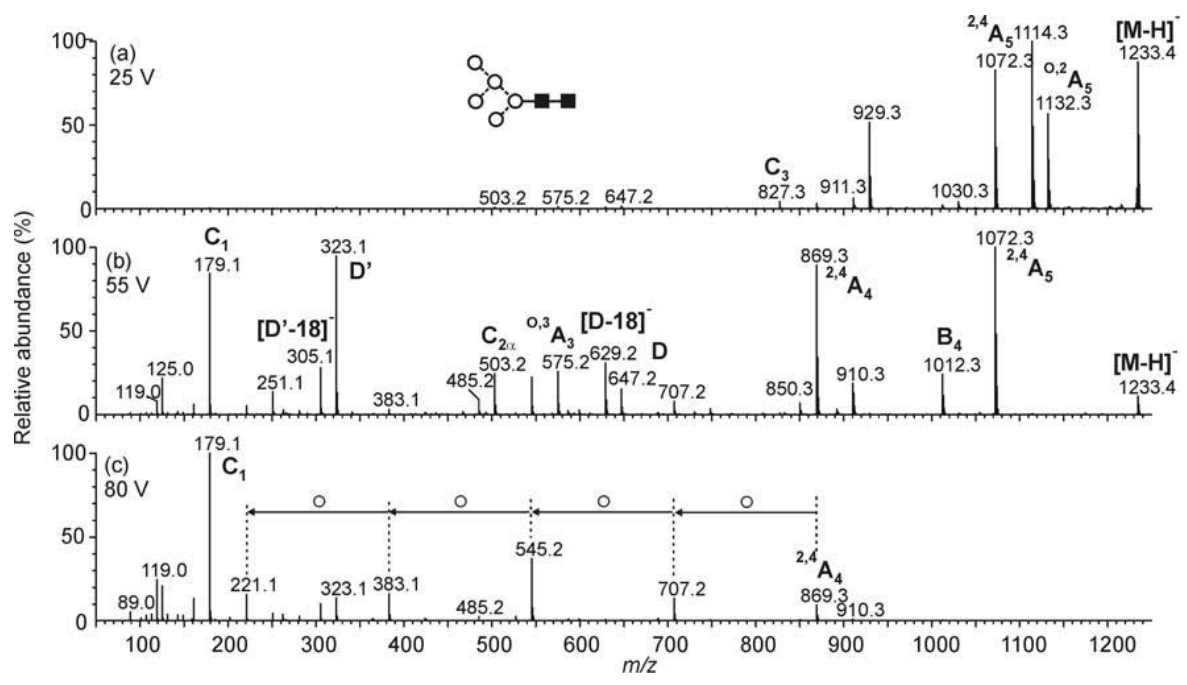

Figure 6. CID spectra of the $[\mathrm{M}-\mathrm{H}]^{-}$ion from the high-mannose glycan (Man) $)_{5}(\mathrm{GlcNAc})_{2}(2)$ recorded at a collision cell potential of (a) $15 \mathrm{~V}$, (b) $55 \mathrm{~V}$, and (c) $80 \mathrm{~V}$.

anisms for their formation have not been proposed. The ion was accompanied by another, 18 mass units lower $(\mathrm{m} / \mathrm{z}$ 629.3), produced, presumably, by a further loss of water. As an illustration of the diagnostic nature of these ions, it was observed that they did not shift in the spectra of $(\mathrm{Man})_{7}(\mathrm{GlcNAc})_{2}, \mathrm{~d} 3^{\circ}$ adducts $^{\circ}\left(4\right.$, Figure $\left.^{\circ} 3 \mathrm{~d}\right)$, whereas they shifted to $\mathrm{m} / \mathrm{z} 808.4 / 791.4$ and $\mathrm{m} / \mathrm{z}$ 971.4/ 953.4 in the spectra of $(\mathrm{Man})_{8}(\mathrm{GlcNAc})_{2^{\circ}}{ }^{\circ} \mathrm{d} 1, \mathrm{~d}^{\circ}(6$, , Figure $3 \mathrm{e})^{\circ}$ and $^{\circ}(\mathrm{Man})_{9}\left(\mathrm{GlcNAc}_{2}\right.$ (7, Figure 3f), ,respectively, as the latter two glycans had one and two extra mannose residues respectively in the 6-antenna. Two sets of ions were present in the isomeric $(\mathrm{Man})_{7}(\mathrm{GlcNAc})_{2}$ glycans (5) from porcine thyroglobulin (data not shown) allowing their relative amounts to be calculated.

In the positive ion spectra, ions of the mass of ion $D$ have been shown to be produced by a $B_{R-1} / Y$ mechanism $^{\circ}$ where ${ }^{\circ}$ the ${ }^{\circ} Y$-cleavage ${ }^{\circ} s^{\circ}$ that ${ }^{\circ}$ of ${ }^{\circ}$ the 3 -antenna $[38]$. However, it is more likely that in these negative ion spectra, which show a strong tendency to produce $C$ rather than $B$ ions, that the mechanism is a $C_{R-1} / Z$

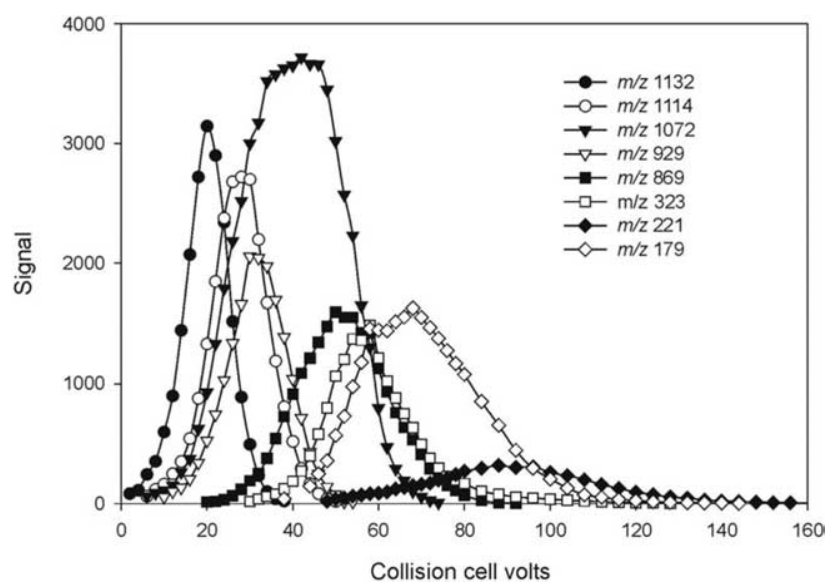

Figure 7. Energy-resolved spectrum of fragment ions from the $[\mathrm{M}-\mathrm{H}]^{-}$ion from (Man $)_{5}(\mathrm{GlcNAc})_{2}(2)$. cleavage, with the Z-cleavage involving the migration of a hydrogen atom to the neutral fragment. A chargeinitiated mechanism for the formation of the D-ions from the $C_{R-1}$ fragment involving migration of the hydrogen from the $\mathrm{OH}$ group at $\mathrm{C}-2$ of the branching mannose is proposed in Scheme 7. The charged oxygen atom of Ion $f$ is again stabilized by conjugation and contains the 4-OH group in an allylic position from where it could readily be lost to give the $[\mathrm{M}-18]^{-}$ion. The structure of the D ion (Ion $f$ ) was supported by its $\mathrm{MS}^{3^{\circ}}$ spectrum $\left.^{\circ}\left(\left[\mathrm{M}^{\circ}-{ }^{\circ} \mathrm{H}\right]^{-} \rightarrow m / z 647.29 e\right]^{\circ} \rightarrow\right)^{\circ}($ Figure $8 \mathrm{a})$ from (Man) $)_{5}(\mathrm{GlcNAc})_{2}(2)$ which showed a loss of 72 mass units corresponding to C-2-C-4 and a loss of 144 mass units representing the residue of the cleaved branching mannose ring (see Scheme 7). The product of this second cleavage $\left(\mathrm{m} / \mathrm{z}\right.$ 503.2) corresponds to the $\mathrm{C}_{2 \alpha}$ ion whose fragmentation is discussed below and whose fragmentions ${ }^{\circ}$ were ${ }^{\circ}$ also ${ }^{\circ}$ present ${ }^{\circ}$ in ${ }^{\circ}$ the ${ }^{\circ} \mathrm{MS}^{3^{\circ}}$ spectrum ${ }^{\circ}$ of Ion $^{\circ} f$ (Figure $8 \mathrm{a}$ ).

The substitution pattern ( 3 and 6) of the mannose residue linked to the 6-position of the core mannose in the high-mannose glycans is the same as that of the branching mannose itself. Consequently, similar fragment ions would be expected following formation of the appropriate C-fragment. Such a C-type ion $(\mathrm{m} / \mathrm{z}$ $503.3, g$ ) can be formed by the mechanism shown in Scheme 8 or following abstraction of protons from the 2- or 4-positions of the branching mannose residue. An $\mathrm{MS}^{3}$ spectrum from this $\mathrm{C}_{2 \alpha}$ ion $(\mathrm{m} / \mathrm{z}$ 503.2) derived from $(\mathrm{Man})_{5}(\mathrm{GlcNAc})_{2}(2)^{\circ}\left(\text { Figure }^{\circ} 8 \mathrm{~b}\right)^{\circ}$ contained $^{\circ}$ an abundant ion at $\mathrm{m} / \mathrm{z} 323.1$ corresponding to the $\mathrm{D}$ ion from the parent molecule. This ion was termed the $\mathrm{D}^{\prime}$ ion. Also formed were the $[\mathrm{m} / \mathrm{z} 323.1-18]^{-}$ion $\left(\left[\mathrm{D}^{\prime}-\right.\right.$ $18]^{-}, m / z$ 305.1) and the $C_{1}$ ion at $m / z$ 179.0. Fragmentation of the $\mathrm{C}_{2 \alpha}$-ion also produced the ion D-equivalent at $\mathrm{m} / \mathrm{z} 323.1$ in the spectrum of (Man) ${ }_{6}(\mathrm{GlcNAc})_{2}(3$ Figure $\left.^{\circ} 3 \mathrm{c}\right),{ }^{\circ}$ and $^{\circ}$ at $^{\circ} \mathrm{m} / z$ $485.2^{\circ}$ in $^{\circ}$ the ${ }^{\circ}$ spectra ${ }^{\circ}$ of ${ }^{\circ}$ the ${ }^{\circ}$ other three glycans (Man $)_{7-9}(\mathrm{GlcNAc})_{2}{ }^{\circ}(4-7 \text {, Figure } 3 \mathrm{~d}-\mathrm{f})^{\circ}$ that 


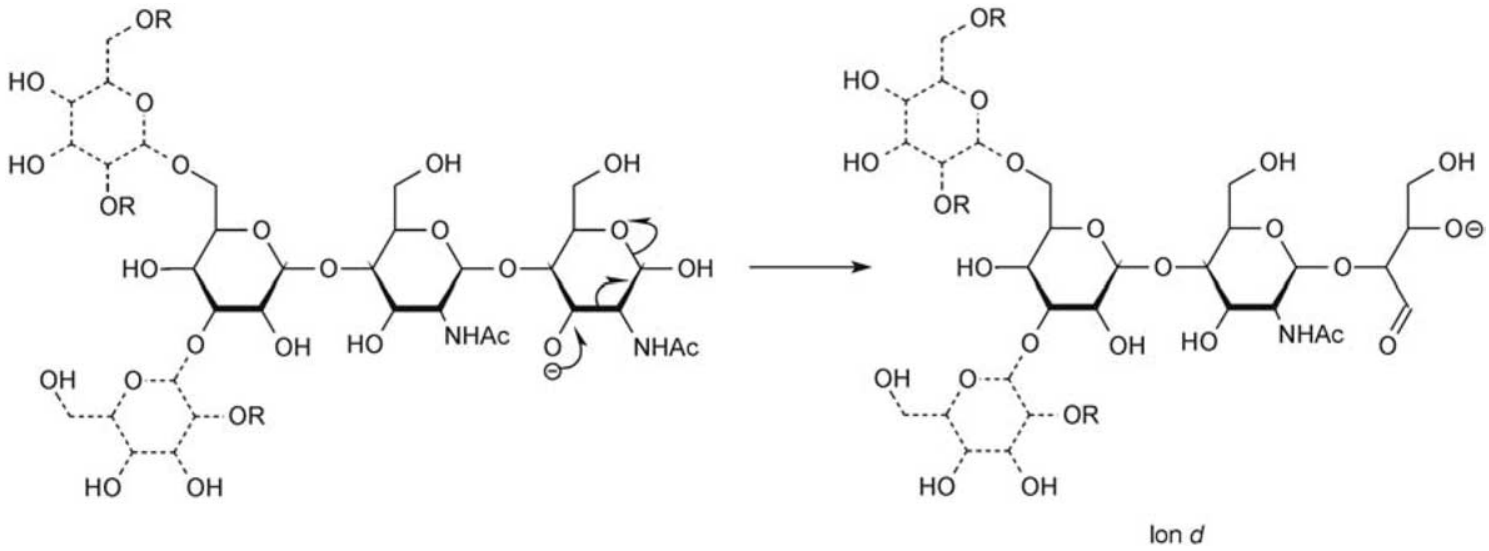

Scheme 5. Proposed mechanism for the formation of the ${ }^{\mathrm{O}, 2} \mathrm{~A}_{\mathrm{R}}$ ion (Ion $d$ ).

contain an extra mannose residue on the 6-branch of the 6-antenna. The spectra of $(\mathrm{Man})_{8}(\mathrm{GlcNAc})_{2} \cdot \mathrm{d} 1 \mathrm{~d} 3$ (6) and $(\mathrm{Man})_{9}\left(\mathrm{GlcNAc}_{2^{\circ}}(7) \text { Figures }^{\circ} 3 \mathrm{f}^{\circ} \text { and }^{\circ} 9 \mathrm{a}\right)^{\circ}$ also $^{\circ}$ contained an ion at $m / z 323.1$ but, in these cases it was not accompanied by the $\left[\mathrm{D}^{\prime}-18\right]^{-}$ion and was, in fact, produced by the $\left[C_{2 \alpha}-18\right]^{-}$fragment. The $C_{2 \alpha}$ ion itself was present at $\mathrm{m} / \mathrm{z}$ 341.2. Similar ions were present in the spectra of the glycans 8 and 9 that had extended 3 -antenna ${ }^{\circ}$ Figure $^{\circ} 3 \mathrm{~g}^{\circ}$ and $^{\circ}$ Figure $\left.^{\circ} 10\right)$. $^{\circ}$ Thus, ${ }^{\circ}$ the ${ }^{\circ} \mathrm{D}^{\prime \circ}$ and

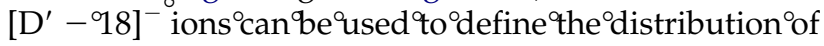
mannose residues on the two branches of the 6-antenna. In the spectrum of $(\mathrm{Man})_{3}(\mathrm{GlcNAc})_{2^{\circ}}\left(\mathbf{1}\right.$, Figure $\left.^{\circ} 3 \mathrm{a}\right)$, $^{\circ}$ the $\mathrm{D}^{\prime}$ and $\left[\mathrm{D}^{\prime}-18\right]^{-}$ions we absent but the $\mathrm{D}$ and $\left[\mathrm{D}^{\prime}-\right.$ $18]^{-}$ions appeared at the mass occupied by the $\mathrm{D}^{\prime}$ and
$\left[\mathrm{D}^{\prime}-18\right]^{-}$ions from $(\mathrm{Man})_{5}(\mathrm{GlcNAc})_{2}$, reflecting the common structure.

Ions produced by abundant ${ }^{\mathrm{O}, 3} \mathrm{~A}_{\mathrm{R}-2}$ cross-ring cleavages that also specified the composition of the 6antenna were present in these spectra as exemplified by the ion at $m / z 575.3$ in the spectrum ${ }^{\circ} f^{\circ}(\mathrm{Man})_{5}(\mathrm{GlcNAc})_{2}(\mathbf{2}$, Figure $\left.{ }^{\circ} 3 b\right)$. ${ }^{\circ}$ They ${ }^{\circ}$ shifted ${ }^{\circ} n^{\circ}$ the ${ }^{\circ}$ same $^{\circ}$ manner ${ }^{\circ}{ }^{\circ}{ }^{\circ}$ the ${ }^{\circ}$-ion pair in the spectra of (Man) $)_{6-9}\left(\right.$ GlcNAc) $2^{\circ}\left(3-7\right.$, Figure $\left.{ }^{\circ} 3\right)$. An $\mathrm{MS}^{3}$ fragmentation of the ${ }^{\mathrm{O}, 3} \mathrm{~A}_{3}$.ion ${ }^{\circ}\left(\mathrm{m} / \mathrm{z}\right.$ 575.3, ${ }^{\circ}$ Figure $8 \mathrm{c})^{\circ}$ from $^{\circ}(\mathrm{Man})_{5}(\mathrm{GlcNAc})_{2}$ (2), showed a loss of 72 mass units to give the $\mathrm{C}_{2 \alpha}$ fragment ${ }^{\circ}$ at $\mathrm{m} / z$ 503.2, ${ }^{\circ}$ consistent ${ }^{\circ}$ with

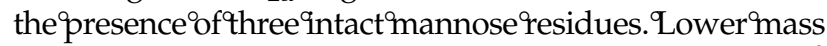
fragments that were identical to those seen in the $\mathrm{MS}^{3}$ spectrum $^{\circ}$ of ${ }^{\circ} \mathrm{m} / \mathrm{z} 503.2^{\circ}$ (Figure $\left.^{\circ} 8 \mathrm{~b}\right)^{\circ}$ were $^{\circ}$ also $^{\circ}$ present. $^{\circ} \mathrm{A}$
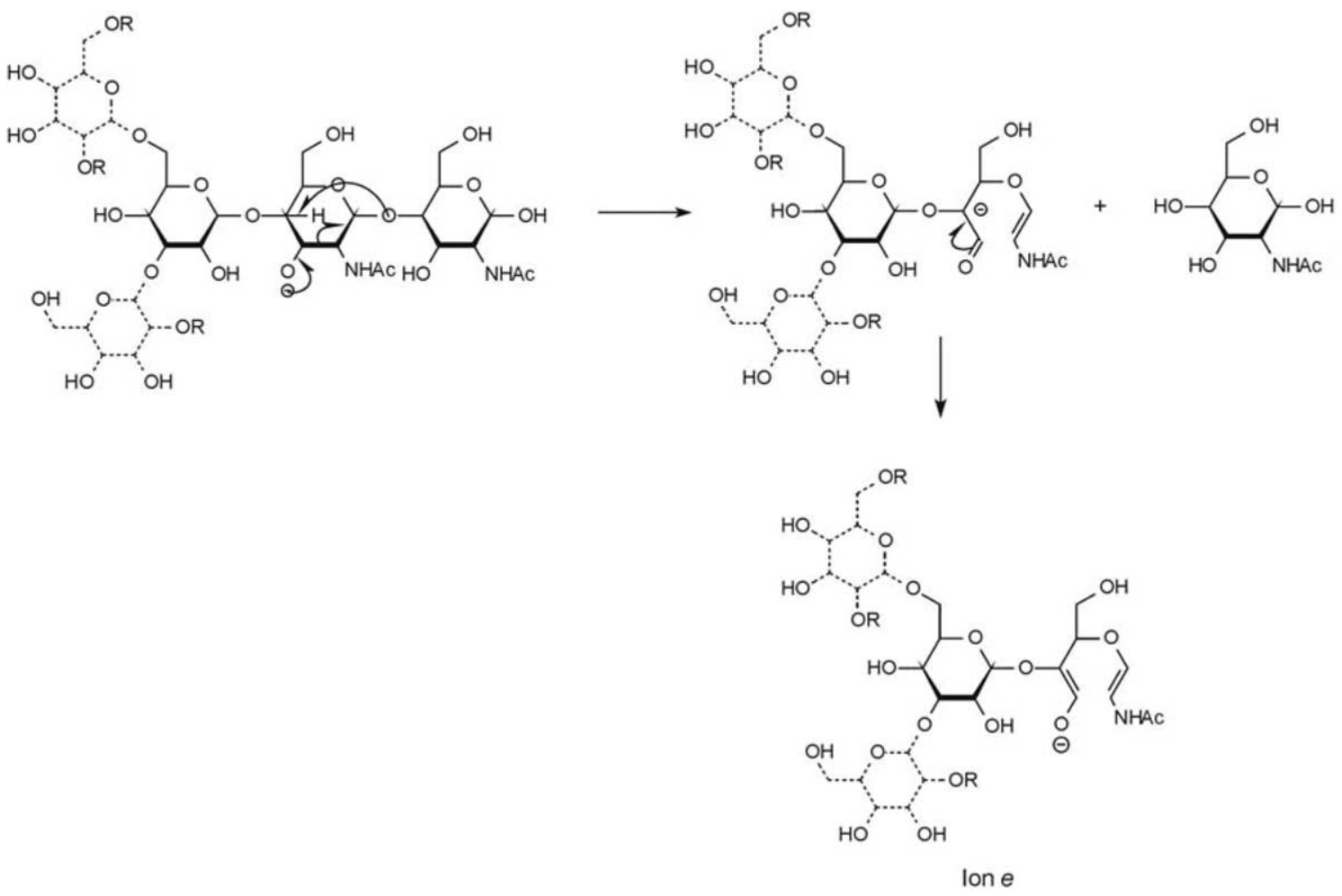

Scheme 6. Proposed mechanism for the formation of the $\mathrm{B}_{\mathrm{R}}$ ion (Ion e). 


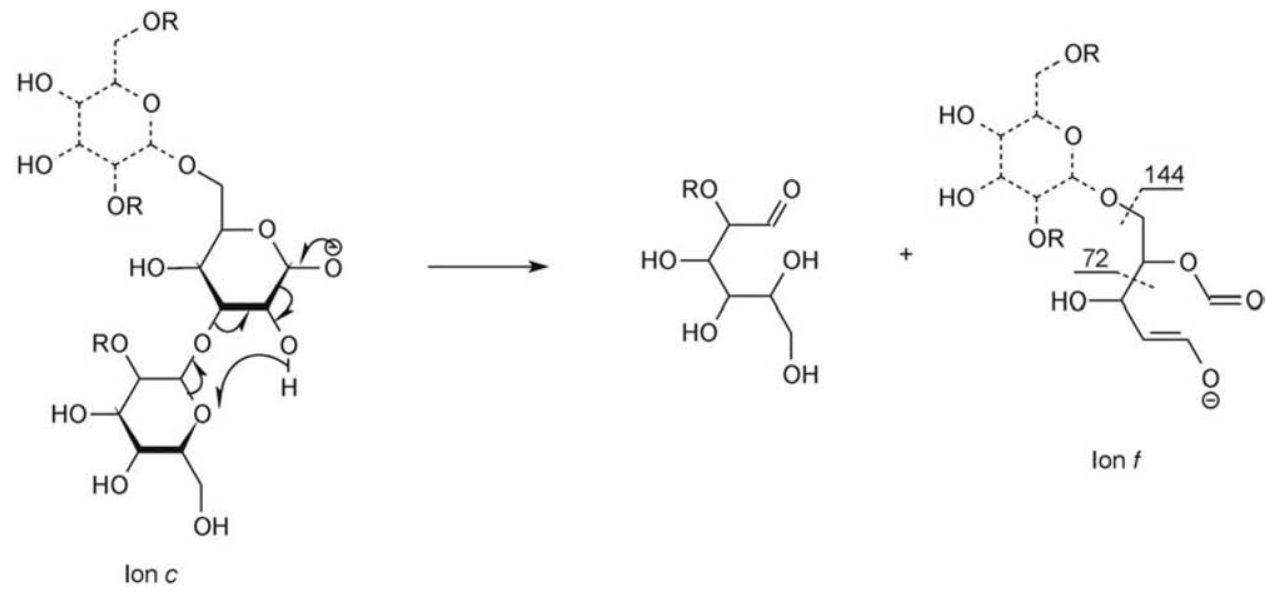

Scheme 7. Proposed mechanism for the formation of Ion D (Ion $f$ ), diagnostic for the composition of the 6-antenna.

structure (Ion $h$ ) is suggested for this cross-ring cleavage ion in Scheme 9. Formation of this ion involves the loss of a hydrogen atom (or, more probably, transfer of a hydrogen atom to the neutral fragment) and Scheme 9 shows a suggested fragmentation route from the $C$ fragment, Ion $c$. The hydrogen atom at C-5 of the branching mannose is very favourably positioned to react with the 2-hydroxy group of ion $c$, but with none other, if the ring is in the boat conformation. This mechanism would produce a conjugated neutral fragment and resonance-stabilized ionized enol (Ion $h$ ) shown in Scheme 9.

Several other cross-ring cleavage ions, in addition to the ${ }^{2,4} \mathrm{~A}_{\mathrm{R}}$ and ${ }^{2,4} \mathrm{~A}_{\mathrm{R}-1}$ ions, that retained two carbon atoms from the cleaved ring were present in these spectra. The most significant was that formed from an ${ }^{0,4} \mathrm{~A}$ cleavage of the core mannose which, again specified the composition of $^{\circ}$ the $^{\circ} 6$-antenna. ${ }^{\circ}$ This $^{\circ}$ ion $^{\circ}$ appeared ${ }^{\circ}$ at $^{\circ} \mathrm{m} / z 545.2^{\circ}$ in ${ }^{\circ}$ the spectra of $(\mathrm{Man})_{5}(\mathrm{GlcNAc})_{2} \quad\left(\right.$, Figures $^{\circ} 3 \mathrm{~b}^{\circ}$ and $\left.^{\circ} 4 \mathrm{a}\right)$,
$(\mathrm{Man})_{6}(\mathrm{GlcNAc})_{2^{\circ}}(3 \text {, Figure } 3 \mathrm{c})^{\circ}$ and $^{\circ}(\mathrm{Man})_{7}(\mathrm{GlcNAc})_{2^{\circ}} \cdot \mathrm{d} 3$, isomer $\left.^{\circ} 1\right)^{\circ}\left(4\right.$, Figure $\left.^{\circ} 3 \mathrm{~d}\right){ }^{\circ} 707.2^{\circ}$ in $^{\circ}$ the $^{\circ}$ spectra $^{\circ}$ of $(\mathrm{Man})_{7}(\mathrm{GlcNAc})_{2}$ isomer 2 (5) and $(\mathrm{Man})_{8}(\mathrm{GlcNAc})_{2}$ (6, Figure $\left.^{\circ} 3 \mathrm{e}\right)^{\circ}$ and $^{\circ}$ at $^{\circ} \mathrm{m} / \mathrm{z} \quad 869.3^{\circ}$ in $^{\circ}$ the $^{\circ}$ spectrum $^{\circ}$ of

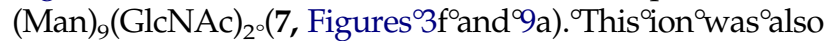
observed $^{\circ}$ by $^{\circ}$ Sagi $^{\circ}$ et $^{\circ}$ al. ${ }^{\circ}[7]^{\circ}$ who $^{\circ}$ also $^{\circ}$ proposed $^{\circ}$ an $^{\circ \mathrm{O}, 4} \mathrm{~A}$ cleavage ${ }^{\circ}$ for ${ }^{\circ}$ its ${ }^{\circ}$ formation ${ }^{\circ}$ but $^{\circ}$ without ${ }^{\circ}$ suggesting ${ }^{\circ}{ }^{\circ}$ mechanism. The structure of this ion appears to be that of (ion i) shown in Scheme $\mathbf{1 0}$ and for which a mechanism for its formation is now proposed. Again, this mechanism proposes initial proton abstraction from a hydroxy group, this time from the 2-position of the branching mannose residue, although hydrogen abstraction from the 4-position would give a similar reaction, and formation of an ionized enol fragment. $\mathrm{MS}^{3}$ Fragmentation of this ion showed mainly successive eliminations of mannose residues attesting to its stability and supporting the ionized enol structure.

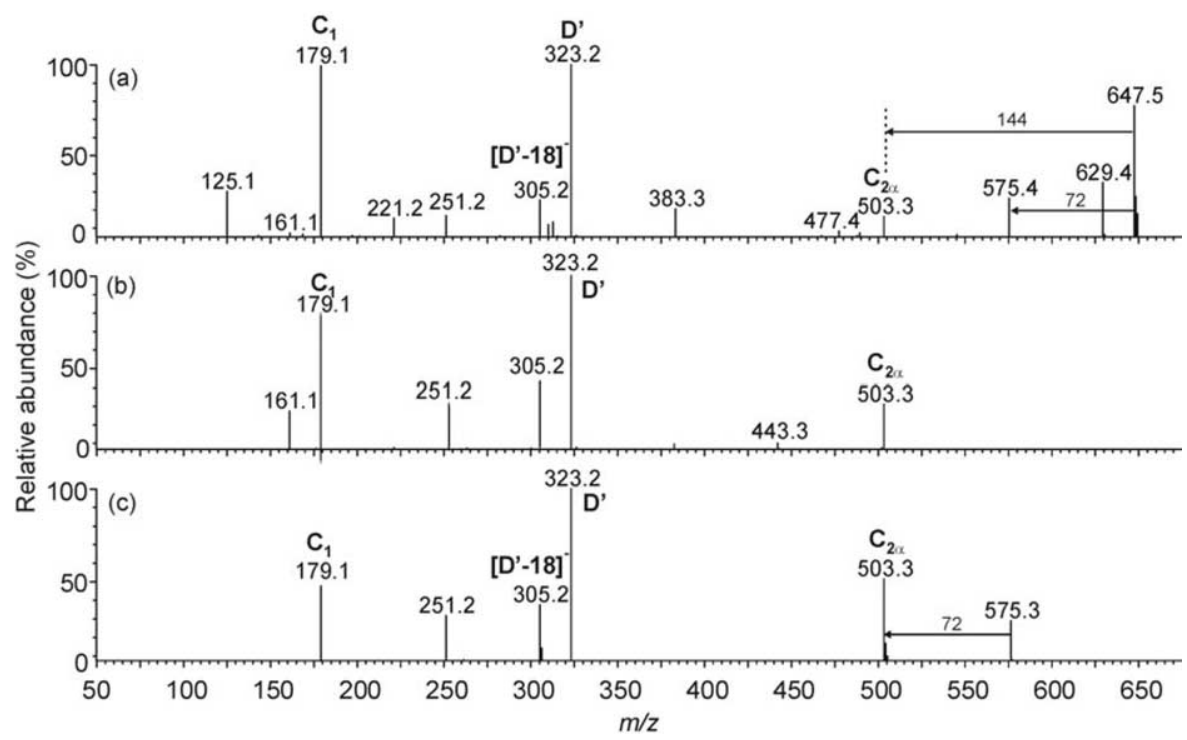

Figure 8. $\mathrm{MS}^{3}$ Spectra of (a) the D ion $(m / z$ 647.3, Ion $f)$, (b) the $\mathrm{C}_{2 \mathrm{a}}$ ion $(\mathrm{m} / \mathrm{z} 503.2)$, and (c) the ${ }^{\mathrm{O}, 3} \mathrm{~A}_{3}$ ion (Ion $h, m / z$ 575.3) from (Man) $)_{5}\left(\mathrm{GlcNAc}_{2}\right.$ (2). 


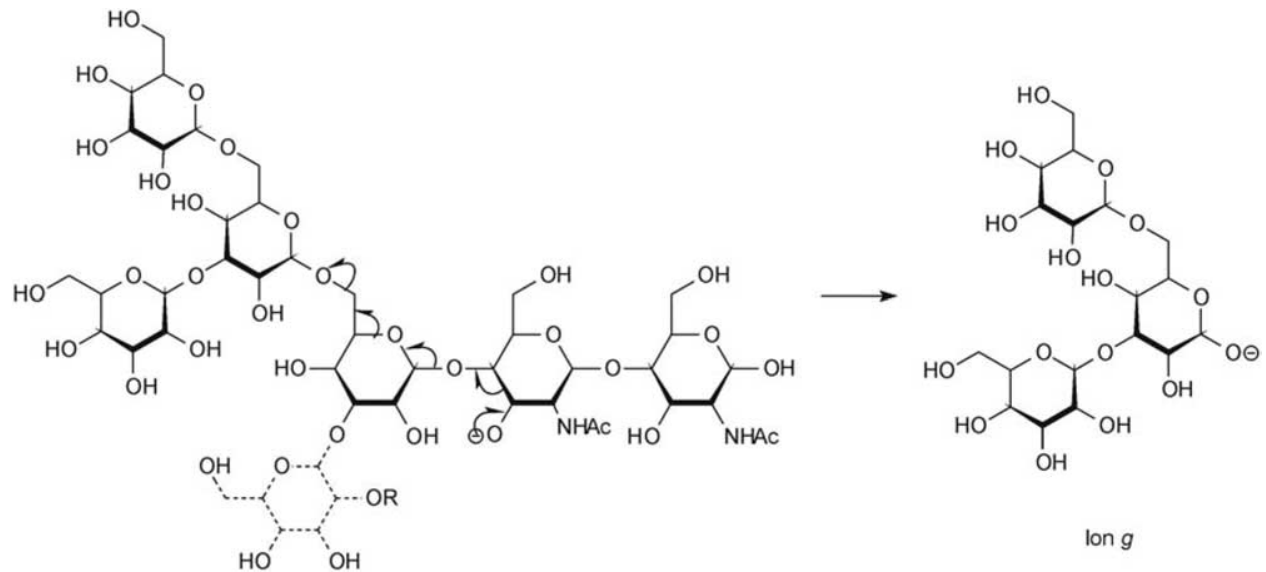

Scheme 8. Proposed mechanism for the formation of the $\mathrm{C}_{2 \mathrm{a}}$ ion (Ion $g$ ) from (Man $)_{5}(\mathrm{GlcNAc})_{2}$.

\section{Glycans with Extended 3-Antennas}

Compounds 9-12 possessed 3-antennas containing three additional glucose residues, a structural feature that considerably modified the general pattern of fragmentation seen for the above glycans. Although the ${ }^{2,4} \mathrm{~A}_{\mathrm{R}}{ }^{2,4} \mathrm{~A}_{\mathrm{R}-1}$, and $\mathrm{B}_{\mathrm{R}}$ ions were still very abundant, the ions towards the centre of the spectra were considerably different ${ }^{\circ}$ to ${ }^{\circ}$ those ${ }^{\circ}$ see $^{\circ}$ earlier $^{\circ}$ (Figure 10$)$. The $^{\mathrm{ol}, 3} \mathrm{~A}_{\mathrm{R}-3}$ and ${ }^{1,3} \mathrm{~A}_{\mathrm{R}-4}$ ions at $m / z 869.4$ and 707.3, in particular, were very abundant. These ions would appear to have been formed by initial abstraction of the hydrogen atom from the 3-hydroxy group of the two 2-linked mannose residues of the 3-antenna by a mechanism similar to that shown in Scheme 1. However, $\mathrm{MS}^{3}$ spectra of the ${ }^{2,4} \mathrm{~A}_{\mathrm{R}}$ and ${ }^{2,4} \mathrm{~A}_{\mathrm{R}-1}$ ions indicated that, in common with the $\mathrm{D}$ and $[\mathrm{D}-18]^{-}$ions, the two ${ }^{1,3} \mathrm{~A}$ ions were

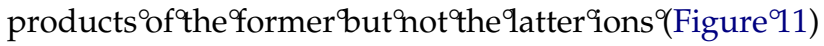
suggesting a more specific, but as yet undetermined, mechanism. It is significant, however, that formation of these ions both involved cleavages of $\alpha 1 \rightarrow 2$-linked mannose residues, possibly indicating a diagnostic fragmentation for these bonds. In the spectrum of

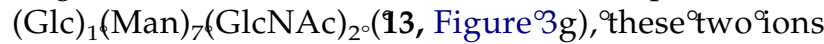
appeared at $m / z 545.2$ and 383.2, respectively, reflecting the absence of the two terminal glucose residues.

A series of three ions corresponding to B-type cleavages of the 3-antenna appeared at $\mathrm{m} / \mathrm{z} 647,809.3$ and $971.3\left(B_{R-2}, B_{R-3}\right.$ and $\left.B_{R-4}\right)$, respectively, in the spectra of the glycans with three glucose residues in the 3-antenna (Figure 10). Differentiation between ${ }^{\circ}$ the $^{\circ}$ structure $^{\circ}$ of the ion at $m / z 647.3$ and a possible $\mathrm{D}$ ion of the same mass could be made on the basis of the lack of a [D -18$]^{-}$ ion. Although these ions involved cleavages adjacent to mannose residues, their relative abundance did not appear to be linkage-related. The masses of the other four ions in the central region of these spectra (e.g., $\mathrm{m} / \mathrm{z}$

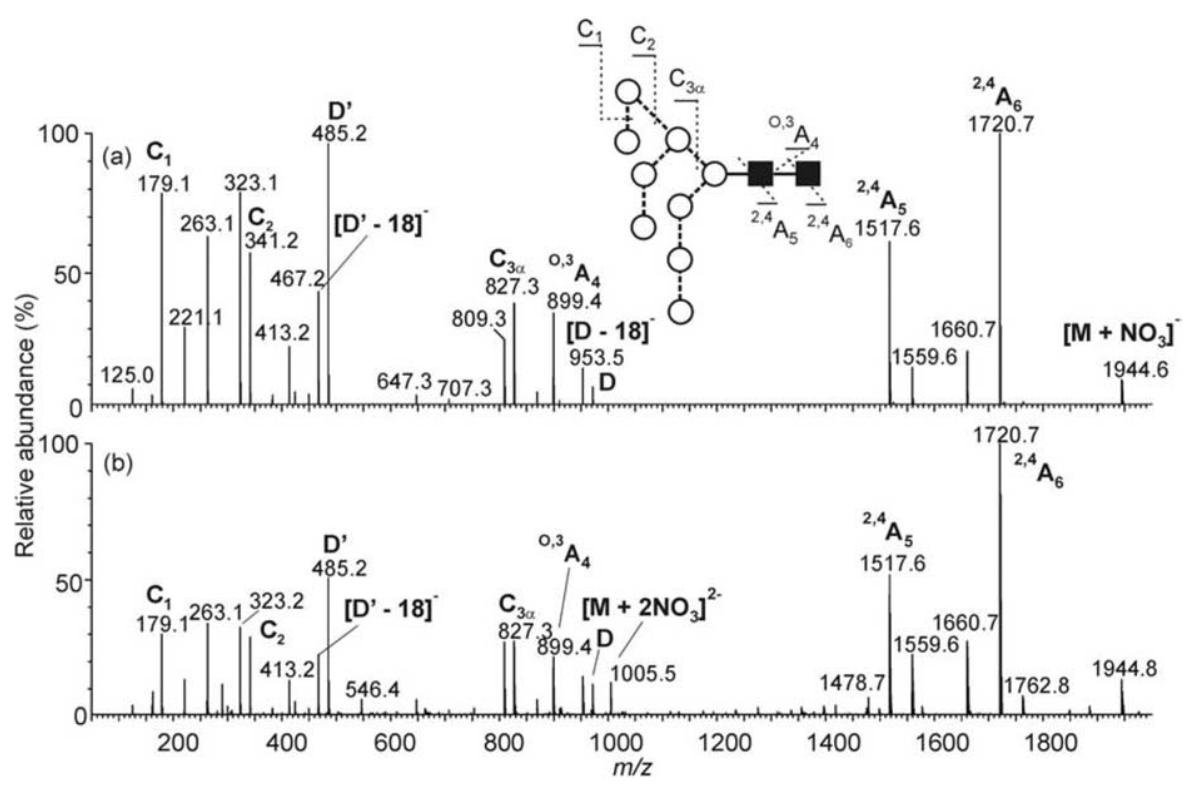

Figure 9. CID Spectra of (a) the $\left[\mathrm{M}+\mathrm{NO}_{3}\right]^{-}$and (b) the $\left[\mathrm{M}+\left(\mathrm{NO}_{3}\right)_{2}\right]^{2-}$ ions from the high-mannose glycan $(\mathrm{Man})_{9}(\mathrm{GlcNAc})_{2}(7)$. 

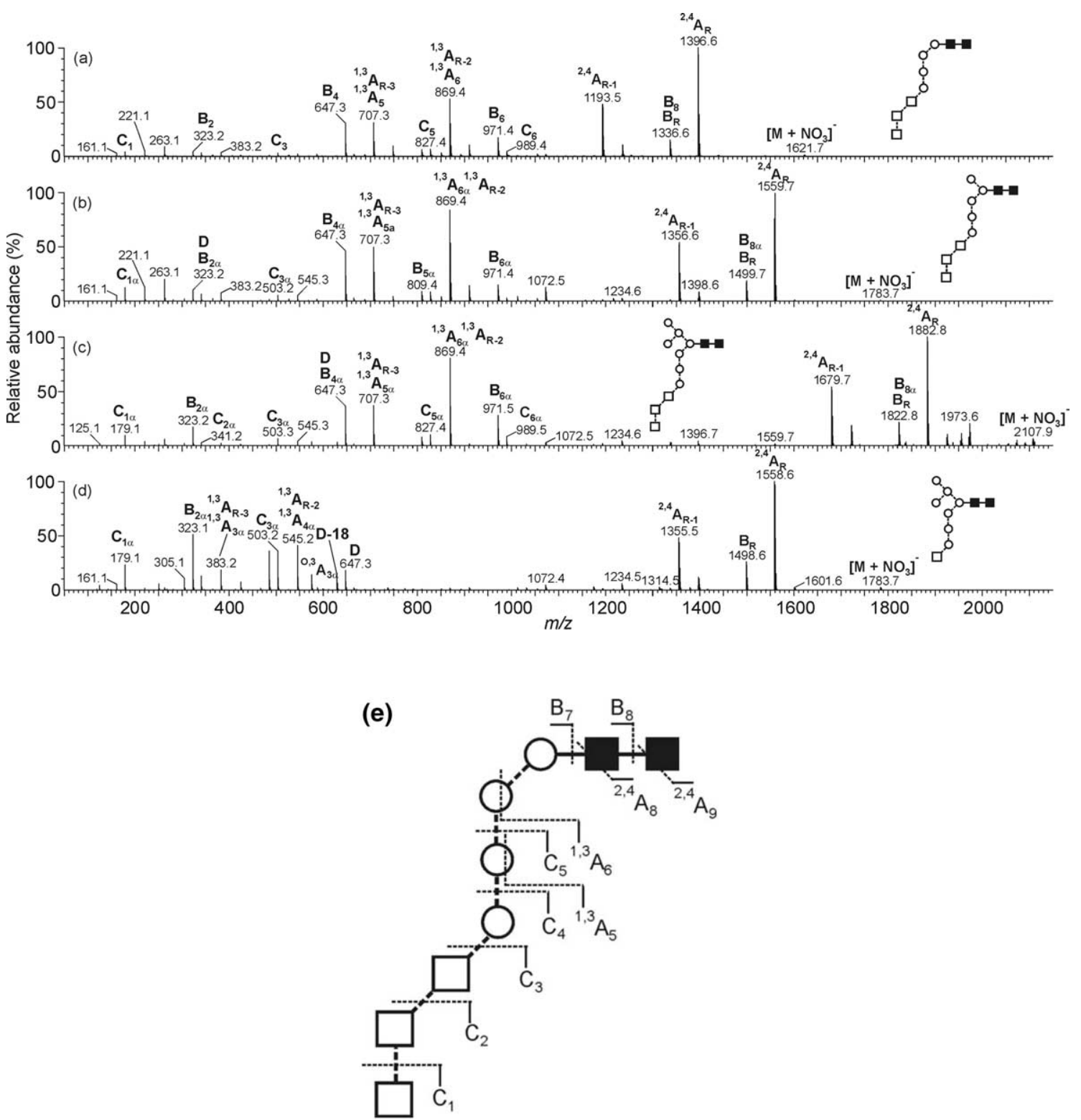

Figure 10. CID Spectra of the $\left[\mathrm{M}+\mathrm{NO}_{3}\right]^{-}$ions from the glucose-containing high-mannose glycans (a) $(\mathrm{Glc})_{3}(\mathrm{Man})_{4}(\mathrm{GlcNAc})_{2}(\mathbf{1 2})$, (b) $(\mathrm{Glc})_{3}(\mathrm{Man})_{5}(\mathrm{GlcNAc})_{2}(\mathbf{1 1})$, and (c) $(\mathrm{Glc})_{3}(\mathrm{Man})_{7}(\mathrm{GlcNAc})_{2}(\mathbf{1 0})$,

(d) $(\mathrm{Glc})_{1}(\mathrm{Man})_{7}(\mathrm{GlcNAc})_{2}$. (e) Shows the fragmentation scheme for $(\mathrm{Glc})_{3}(\mathrm{Man})_{4}(\mathrm{GlcNAc})_{2}$.

$586.3,{ }^{\circ} 748.3,^{\circ} 910.4^{\circ}$ and $^{\circ} 1072.5^{\circ}$ Figure $\left.^{\circ} 10 a\right)^{\circ}$ shifted $^{\circ}$ in mass with the size of the 6-antenna and corresponded to ${ }^{2,4} A_{R} / B_{6}-B_{3}$ ions, respectively.

\section{Other Ions Revealing Antenna Composition}

Abstraction of protons from hydroxy groups positioned on the carbon atom adjacent to a linkage position (as in Schemes 1 and 3) generally appeared to initiate cleavages in which the product ion had the mass of intact sugar rings plus 59 mass units. These ions, such as that at $\mathrm{m} / \mathrm{z} 221\left([\mathrm{Hex}+59]^{-}\right.$, Ion $\left.j\right)$ in the spectra of the high-mannose glycans were weak in the spectra recorded at the collision energy used for the spectra in this paper but became progressively more abundant as the collision energy was raised such that they were the most abundant ions in the spectra at energies of around $80 \mathrm{eV}$ (for $[\mathrm{Man}]_{5}[\mathrm{GlcNAc}]_{2}$ ) (2, Figure ${ }^{\circ} 6 \mathrm{c}$ ). ${ }^{\circ}$ They $^{\circ}$ were presumably formed by mechanisms similar to that shown in Scheme $\mathbf{1}$ following hydrogen abstraction from a hydroxy group from a sugar ring near the non-reducing terminus or by the mechanism mentioned above whereby the proton was abstracted by the charge site of a previously-formed ion.

\section{Compounds with Truncated Core Structures}

Glycans released from glycoproteins with endoglycosidase $\mathrm{H}$ contain only one GlcNAc residue in the core region (e.g., Compound 14). Fragmentation of these 


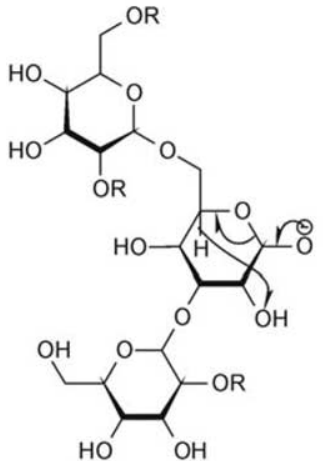

Ion $c$
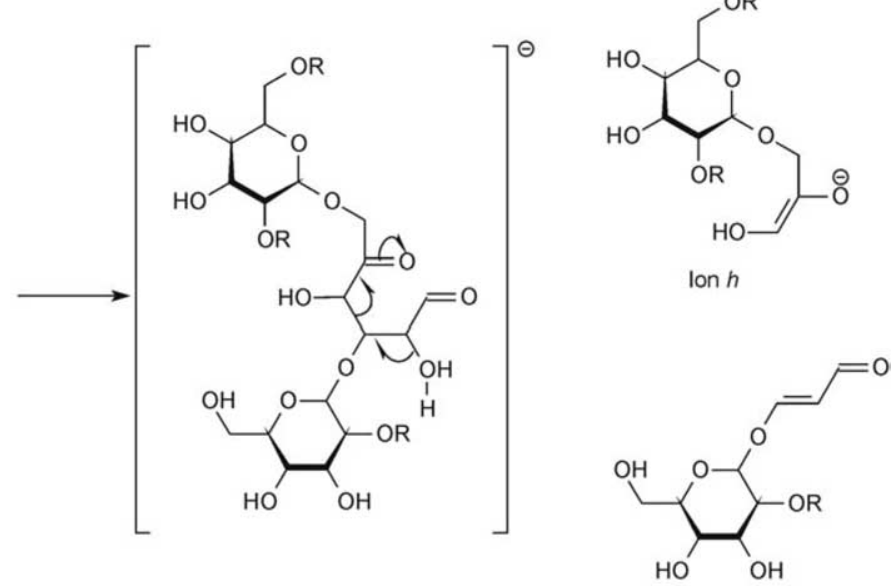

Neutral fragment

Scheme 9. Proposed mechanism for the formation of the ${ }^{0,3} \mathrm{~A}_{3}$ ion (Ion $h$ ).

compounds was virtually identical to that of the corresponding compounds that contained two GlcNAc residues with the exception that the ${ }^{2,4} A_{R}$ and $B_{R}$ ions from the latter compounds were missing. Thus, the ion equivalent of the ${ }^{2,4} \mathrm{~A}_{\mathrm{R}}$ ion from the compounds containing two GlcNAc residues became the ${ }^{2,4} \mathrm{~A}_{\mathrm{R}}$ ion of the compounds containing one GlcNAc in the core.

\section{Fragmentation of Doubly-Charged Ions}

The $[\mathrm{M}-2 \mathrm{H}]^{2-}$ and $\left[\mathrm{M}+\left(\mathrm{NO}_{3}\right)_{2}\right]^{2-}$ ions fragmented with about half of the energy required to cleave the singly-charged ions. The $[\mathrm{M}-2 \mathrm{H}]^{2-}$ ions formed both doubly- and singly-charged fragments with the doubly- charged fragments consisting almost entirely of Y-type losses from the non-reducing terminus and from the doubly-charged ${ }^{2,4} \mathrm{~A}_{\mathrm{R}}$ ion, whereas the singly-charged fragment ions were more varied and carried most of the structural information. However, the higher mass ions were weak.

Increasing voltage on the collision cell initially caused losses of neutral fragments giving doublycharged ions as shown for the $[\mathrm{M}-2 \mathrm{H}]^{2-}$ ion from (Man $)_{6}(\text { GlcNAc })_{2}$ (3, Figure $\left.{ }^{\circ} 12\right)$. ${ }^{\circ}$ Losses ${ }^{\circ}$ occurring $^{\circ}$ at ${ }^{\circ}$ the lowest collision energies (2-16 eV) were cross-ring cleavages resulting in elimination of 101 and 119 mass units (50.5 and $60 \mathrm{u}$ from the doubly-charged molecule, $m / z 646.5$ and 637.5). The loss of 101 mass units was

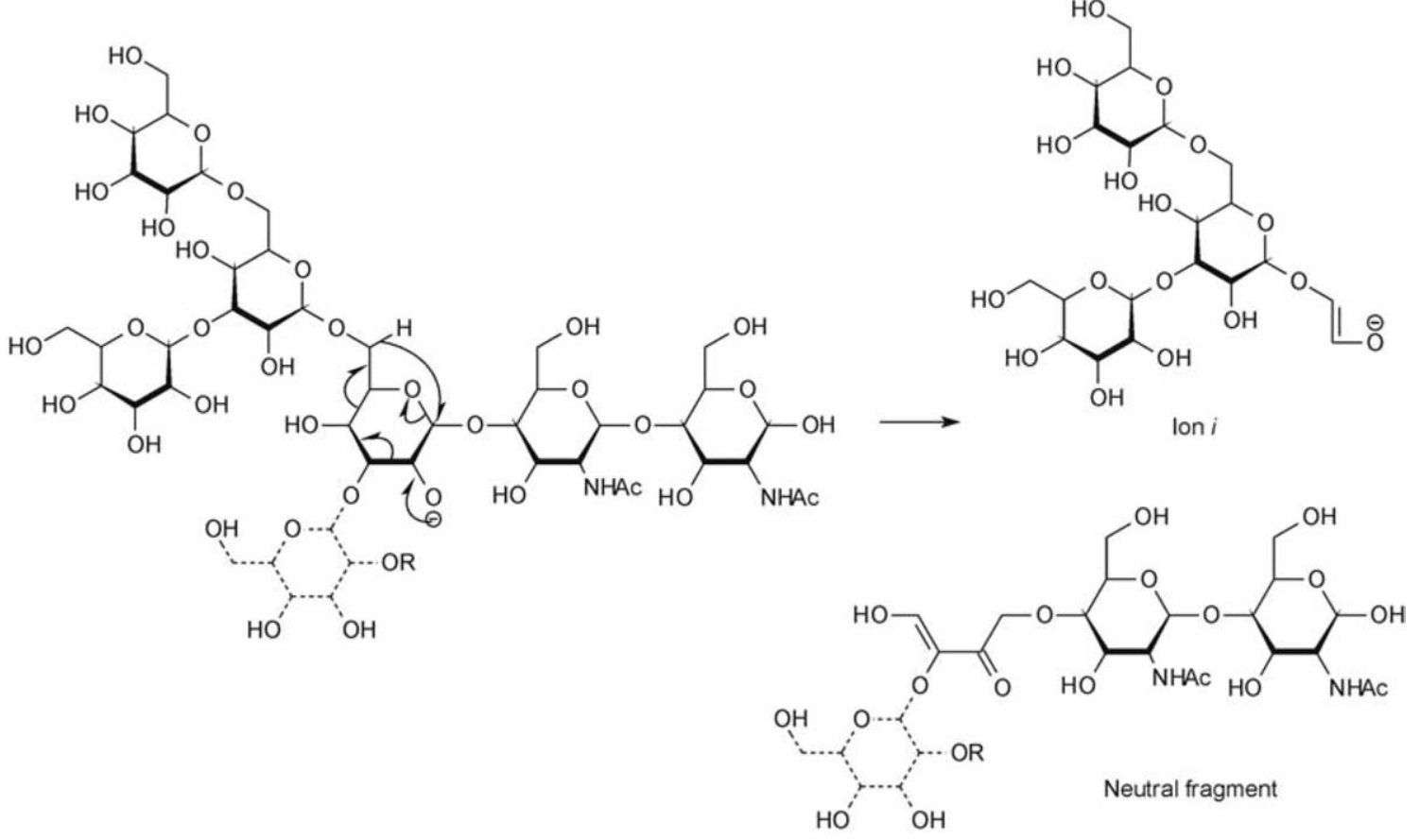

Scheme 10. Proposed mechanism for the formation of the ${ }^{\mathrm{O}, 4} \mathrm{~A}_{3}$ ion (Ion $\left.i\right)$ from $(\mathrm{Man})_{5}(\mathrm{GlcNAc})_{2}$. 


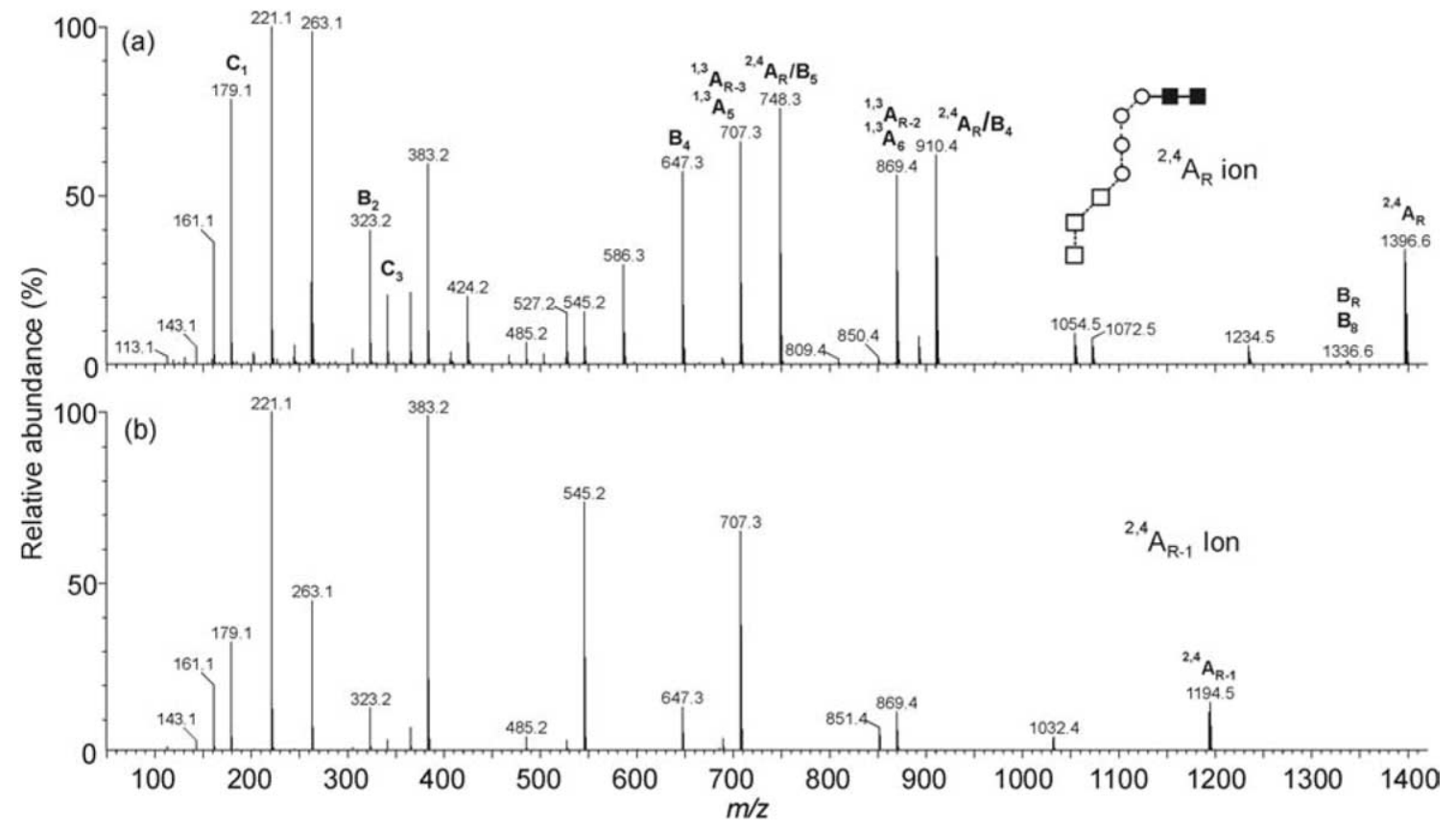

Figure 11. $M S^{3}$ spectra of (a) the ${ }^{2,4} \mathrm{~A}_{\mathrm{R}}$ and (b) the ${ }^{2,4} \mathrm{~A}_{\mathrm{R}-1}$ ion from the glucose-containing high mannose glycan $(\mathrm{Glc})_{3}(\mathrm{Man})_{4}(\mathrm{GlcNAc})_{2}(\mathbf{1 2})$.

probably due to an ${ }^{0,2} \mathrm{~A}$ cleavage of the reducing terminal GlcNAc residue by the mechanism shown in Scheme 5 and was supported by the appearance at slightly higher collision cell voltages of the ion formed by a corresponding cleavage of the other GlcNAc residue $\left.(m / z 545 \text {, [M - 101/2 - 203/2 }]^{2-}\right)$. Corresponding ions formed by the same mass losses were observed in the spectra of other types of $N$-linked glycans. The loss of 119 mass units corresponded to a further loss of water from the ${ }^{\mathrm{O}, 2} \mathrm{~A}_{\mathrm{R}}$ ion. These ions disappeared from the spectra as the voltage on the collision cell rose (Figure $\left.{ }^{\circ} 12\right),{ }^{\circ}$ behavior ${ }^{\circ}$ that ${ }^{\circ}$ was $^{\circ}$ similar $^{\circ}$ to $^{\circ}$ that $^{\circ}$ seen $^{\circ}$ for the singly-charged ions discussed above. At higher voltages $(6-40 \mathrm{eV})$, the doubly-charged ${ }^{2,4} \mathrm{~A}_{\mathrm{R}}$ fragment $(\mathrm{m} / \mathrm{z} 616.5$, loss of $161 / 2$ mass units) became dominant

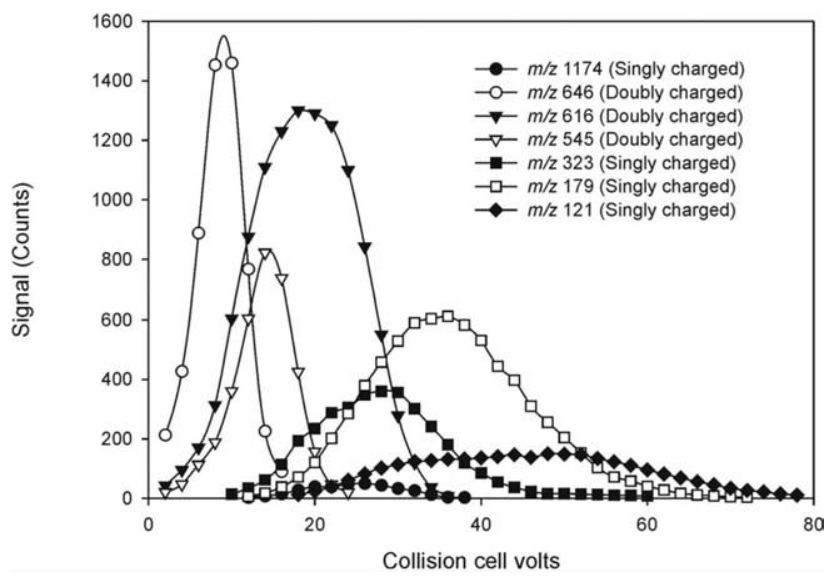

Figure 12. Energy-resolved spectrum of fragments from the $[\mathrm{M}$ $\left.+\left(\mathrm{NO}_{3}\right)_{2}\right]^{2-}$ ion from the high-mannose glycan (Man $)_{6}(\mathrm{GlcNAc})_{2}$ (3). and was accompanied by the corresponding ${ }^{2,4} \mathrm{~A}_{\mathrm{R}-1}$ fragment $(m / z 515.1)$. Both ions lost successive mannose residues as the collision energy rose but all doublycharged fragment ions were absent from the spectrum above about $40 \mathrm{~V}$.

At collision cell potentials of $12 \mathrm{~V}$ and upwards, singly-charged ions appeared with a pattern of fragmentation similar to that seen in the singly-charged spectra. These ions had their maximum intensity in the region of $30 \mathrm{~V}$. At higher voltages the pattern of ions in the spectra of the high-mannose glycans changed to a series of singly-charged ions at $\mathrm{m} / \mathrm{z} 121$, $383,545,707,868$, and 1031 that appeared to be successive losses of mannose residues from the singly-charged ${ }^{2,4} \mathrm{~A}_{4}$ ion. Finally, above $70 \mathrm{eV}$, the mannose residue ion at $\mathrm{m} / \mathrm{z} 161$ was dominant.

Doubly-charged $\left[\mathrm{M}+\left(\mathrm{NO}_{3}\right)_{2}\right]^{2-}$ ions fragmented almost exclusively to singly-charged fragment ions $\left(\text { see }^{\circ} \text { Figure }^{\circ} 9\right)^{\circ}$ with $^{\circ}$ relative $^{\circ}$ abundances ${ }^{\circ}$ comparable $^{\circ}$ to those in the spectra of the $\left[\mathrm{M}+\mathrm{NO}_{3}\right]^{-}$ions. The first fragmentation step, demonstrated by slowly increasing the collision energy, was loss of $\mathrm{NO}_{3}{ }^{-}$to give the singly-charged $\left[\mathrm{M}+\mathrm{NO}_{3}\right]^{-}$ion which fragmented in an identical manner to the ion of this composition that was formed initially as a singlycharged fragment. Carbohydrates adducted with other anions behaved similarly. Thus, because the doubly-charged ions were sometimes formed from the larger glycans in preference to the singly-charged ions, their fragmentation provided a convenient way to obtain singly-charged spectra that were uncluttered by doubly-charged fragment ions. 


\section{Conclusions}

Formation of fragment ions from the nitrate adducts could be rationalized by hydrogen abstraction from random hydroxyl positions of the glycan in direct contrast to earlier postulates that it was mainly the proton from the anomeric hydroxyl group that was eliminated in the formation of $[\mathrm{M}-\mathrm{H}]^{-}$ions. In fact, none of the fragments could be attributed to initial loss of the anomeric proton. The free electron liberated by proton abstraction readily paired with electrons from the sugar ring, producing ring cleavage with the formation of an ionized enol or the formation of a C-fragment when it became localised on a linking oxygen. The ionized enols appeared relatively stable with respect to further charge-initiated processes, whereas the C-fragments decomposed further. C-fragments at branching sugar residues tended to decompose to fragments that were diagnostic of the branching moieties. This behavior accounts for earlier observations that negative ion spectra are rich in cross-ring fragments and some $\mathrm{C}$-ions, whereas the reverse is true for the fragmentation of positive ions which give mainly B- and Y-type glycosidic fragments. The specific fragmentation routes demonstrated by these spectra resulted in ions that revealed specific details about the fragmentation of these glycans; such information included the $1 \rightarrow 4$ linkage of the core GlcNAc residues (presence of the ${ }^{2,4} A_{R}$ and ${ }^{2,4} \mathrm{~A}_{\mathrm{R}-1}$ ions) and the composition of the 6-antenna (D and $\left[\mathrm{D}-\mathrm{H}_{2} \mathrm{O}\right]^{-}$ions, ${ }^{\mathrm{O}, 3} \mathrm{~A}$ fragment of the branching mannose residue) and, by difference, the 3-antenna.

\section{Acknowledgments}

The author thanks Professor R. A. Dwek, Director of the Glycobiology Institute, for his help and encouragement, and Mukram Mackeen for gifts of the IgY glycans. He also thanks the Wellcome Trust for an equipment grant to purchase the Q-TOF mass spectrometer.

\section{References}

1. Wheeler, S. F.; Harvey, D. J. Negative ion mass spectrometry of sialylated carbohydrates: Discrimination of $\mathrm{N}$-acetylneuraminic acid linkages by matrix-assisted laser desorption/ ionization-time-of-flight and electrospray-time-of-flight mass spectrometry. Anal. Chem. 2000, 72, 5027-5039.

2. Chai, W.; Piskarev, V.; Lawson, A. M. Negative-ion electrospray mass spectrometry of neutral underivatized oligosaccharides. Anal. Chem. 2001, 73, 651-657.

3. Pfenninger, A.; Karas, M.; Finke, B.; Stahl, B. Structural analysis of underivatized neutral human milk oligosaccharides in the negative ion mode by nano-electrospray $\mathrm{MS}^{\mathrm{n}}$ (Part 1: Methodology). J. Am. Soc. Mass Spectrom. 2002, 13, 1331-1340.

4. Pfenninger, A.; Karas, M.; Finke, B.; Stahl, B. Structural analysis of underivatized neutral human milk oligosaccharides in the negative ion mode by nano-electrospray $\mathrm{MS}^{\mathrm{n}}$ (Part 2: Application to isomeric mixtures). J. Am. Soc. Mass Spectrom. 2002, 13, 1341-1348.
5. Chai, W.; Piskarev, V.; Lawson, A. M. Branching pattern and sequence analysis of underivatized oligosaccharides by combined MS/MS of singly and doubly charged molecular ions in negative-ion electrospray mass spectrometry. J. Am. Soc. Mass Spectrom. 2002, 13, 670-679.

6. Quéméner, B.; Désiré, C.; Lahaye, M.; Debrauwer, L.; Negroni, L. Structural characterization of both positive- and negative-ion electrospray mass spectrometry of partially methyl-esterified oligogalacturonides purified by semi-preparative high-performance anion-exchange chromatography. Eur. J. Mass. Spectrom. 2003, 9, 45-60

7. Sagi, D.; Peter-Katalinic, J.; Conradt, H. S.; Nimtz, M. Sequencing of tri- and tetra-antennary N-glycans containing sialic acid by negative mode ESI Q-TOF tandem MS. J. Am. Soc. Mass Spectrom. 2002, 13, 1138-1148.

8. Wong, A. W.; Cancilla, M. T.; Voss, L. R.; Lebrilla, C. B. Anion dopant for oligosaccharides in matrix-assisted laser desorption/ionization mass spectrometry. Anal. Chem. 1999, 71, 205211.

9. Wong, A. W.; Wang, H.; Lebrilla, C. B. Selection of anionic dopant for quantifying desialylation reactions with MALDIFTMS. Anal. Chem. 2000, 72, 1419-1425.

10. Cai, Y.; Concha, M. C.; Murray, J. S.; Cole, R. B. Evaluation of the role of multiple hydrogen bonding in offering stability to negative ion adducts in electrospray mass spectrometry. J. Am. Soc. Mass Spectrom. 2002, 13, 1360-1369.

11. Cole, R. B.; Zhu, J. Chloride ion attachment in negative ion electrospray ionization mass spectrometry. Rapid Commun. Mass Spectrom. 1999, 13, 607-611.

12. Zhu, J.; Cole, R. B. Formation and decomposition of chloride adduct ions, $[\mathrm{M}+\mathrm{Cl}]^{-}$, in negative ion electrospray ionization mass spectrometry. J. Am. Soc. Mass Spectrom. 2000, 11, 932941.

13. Zhu, J.; Cole, R. B. Ranking of gas-phase acidities and chloride affinities of monosaccharides and linkage specificity in collision-induced decompositions of negative ion electrospraygenerated chloride adducts of oligosaccharides. J. Am. Soc. Mass Spectrom. 2001, 12, 1193-1204.

14. Cai, Y.; Jiang, Y.; Cole, R. B. Anionic adducts of oligosaccharides by matrix-assisted laser desorption/ionization time-offlight mass spectrometry. Anal. Chem. 2003, 75, 1638-1644.

15. Harvey, D. J. Fragmentation of negative ions from carbohydrates: Part 1. Use of nitrate adducts for the production of negative ion electrospray spectra from $N$-linked carbohydrates. J. Am. Soc. Mass Spectrom. 2005, 16, 622-630.

16. Patel, T.; Bruce, J.; Merry, A.; Bigge, C.; Wormald, M.; Jaques, A.; Parekh, R. Use of hydrazine to release in intact and unreduced form both $\mathrm{N}$ - and O-linked oligosaccharides from glycoproteins. Biochemistry 1993, 32, 679-693.

17. Wing, D. R.; Field, M. C.; Schmitz, B.; Thor, G.; Dwek, R. A.; Schachner, M. S.; Rademacher, T. W. The use of large-scale hydrazinolysis in the preparation of N-linked oligosaccharide libraries: Application to brain tissue. Glycoconjugate J. 1992, 9, 293-301.

18. Da Silva, M. L. C.; Stubbs, H. J.; Tamura, T.; Rice, K. G. ${ }^{1} \mathrm{H}-\mathrm{NMR}$ characterization of a hen ovalbumin tyrosinamide N-linked oligosaccharide library. Arch. Biochem. Biophys. 1995, 318, 465-475.

19. Harvey, D. J.; Wing, D. R.; Küster, B.; Wilson, I. B. H. Composition of $\mathrm{N}$-linked carbohydrates from ovalbumin and co-purified glycoproteins. J. Am. Soc. Mass Spectrom. 2000, 11, 564-571.

20. Fu, D.; Chen, L.; O'Neill, R. A. A detailed structural characterization of ribonuclease $B$ oligosaccharides by ${ }^{1} \mathrm{H}$ NMR spectroscopy and mass spectrometry. Carbohydr. Res. 1994, 261, 173-186. 
21. de Waard, P.; Koorevaar, A.; Kamerling, J. P.; Vliegenthart, J. F. G. Structure determination by ${ }^{1} \mathrm{H}$ NMR spectroscopy of (sulfated) sialylated $N$-linked carbohydrate chains released from porcine thyroglobulin by peptide- $N^{4}$-(N-acetyl- $\beta$-glucosaminyl)asparagine amidase-F. J. Biol. Chem. 1991, 266, 4237-4243.

22. Kamerling, J. P.; Rijkse, I.; Maas, A. A. M.; van Kuik, J. A.; Vliegenthart, J. F. G. Sulfated $N$-linked carbohydrate chains in porcine thyroglobulin. FEBS Letts. 1988, 241, 246-250.

23. Bigge, J. C.; Patel, T. P.; Bruce, J. A.; Goulding, P. N.; Charles, S. M.; Parekh, R. B. Nonselective and efficient fluorescent labeling of glycans using 2-aminobenzamide and anthranilic acid. Anal. Biochem. 1995, 230, 229-238.

24. Domon, B.; Costello, C. E. A systematic nomenclature for carbohydrate fragmentations in FAB-MS/MS spectra of glycoconjugates. Glycoconj. J. 1988, 5, 397-409.

25. Hardy, M. R.; Townsend, R. R. High-pH anion exchange chromatography of glycoprotein-derived carbohydrates. Methods Enzymol. 1994, 230, 208-225.

26. Carroll, J. A.; Willard, D.; Lebrilla, C. B. Energetics of crossring cleavages and their relevance to the linkage determination of oligosaccharides. Anal. Chim. Acta. 1995, 307, 431-447

27. Saad, O. M.; Leary, J. A. Delineating mechanisms of dissociation for iosmeric heparin disaccharides using isotope labeling and ion trap tandem mass spectrometry. J. Am. Soc. Mass Spectrom. 2004, 15, 1274-1286.

28. Neuberger, A.; Wilson, B. M. The separation of glycosides on a strongly basic ion-exchange resin: An interpretation in terms of acidity. Carbohydr. Res. 1971, 17, 89-95.

29. Harvey, D. J. Fragmentation of negative ions from carbohydrates: Part 3. Fragmentation of hybrid and complex $N$-linked glycans. J. Am. Soc. Mass Spectrom. 2005, 16, 647-659.
30. Andersson, B. A.; Holman, R. T. Pyrrolidides for mass spectrometric determination of the position of the double bond in monounsaturated fatty acids. Lipids 1974, 9, 185-190.

31. Andersson, B. A. Mass Spectrometry of fatty acid pyrrolidides. Prog. Chem. Fats Lipids 1978, 16, 279-308.

32. Vetter, W.; Meister, W. Nicotinates as derivatives for the mass spectrometric investigations of long chain alcohols. Org. Mass Spectrom. 1981, 16, 118-122.

33. Harvey, D. J. Picolinyl esters as derivatives for the structural determination of long-chain branched and unsaturated fatty acids. Biomed. Mass Spectrom. 1982, 9, 33-38.

34. Harvey, D. J. Mass spectrometry of picolinyl and other nitrogen-containing derivatives of lipids. In Advances in Lipid Methodology-One; Christie, W. W., Ed.; Oily Press: Ayr, 1992; pp 19-80.

35. Kingston, D. G. I.; Hobrock, B. W.; Bursey, M. M.; Bursey, J. T. Intramolecular hydrogen transfer in mass spectra. III. Rearrangements involving the loss of small neutral molecules. Chem. Rev. 1975, 75, 693-730.

36. Sloan, S.; Harvey, D. J.; Vouros, P. Interaction and rearrangement of trimethylsilyloxy functional groups. The structural significance of the $m / e 147$ ion in the mass spectra of trimethylsilyl steroidal ethers. Org. Mass Spectrom. 1971, 5, 789-799.

37. Harvey, D. J.; Bateman, R. H.; Green, M. R. High-energy collision-induced fragmentation of complex oligosaccharides ionized by matrix-assisted laser desorption/ionization mass spectrometry. J. Mass Spectrom. 1997, 32, 167-187.

38. Harvey, D. J.; Martin, R. L.; Jackson, K. A.; Sutton, C. W. Fragmentation of $\mathrm{N}$-linked glycans with a MALDI-ion trap time-of-flight mass spectrometer. Rapid Commun. Mass Spectrom. 2004, 18, 2997-3007. 